Andrews University

Digital Commons @ Andrews University

2008

\title{
Teacher Perceptions of Their Effectiveness in Supporting Reading Strategies as a Result of Collaboration with a Literacy Coach
}

Sharon S. Miller

Andrews University

Follow this and additional works at: https://digitalcommons.andrews.edu/dissertations

Part of the Educational Leadership Commons, and the Secondary Education Commons

\section{Recommended Citation}

Miller, Sharon S., "Teacher Perceptions of Their Effectiveness in Supporting Reading Strategies as a Result of Collaboration with a Literacy Coach" (2008). Dissertations. 1700.

https://digitalcommons.andrews.edu/dissertations/1700

https://dx.doi.org/10.32597/dissertations/1700

This Dissertation is brought to you for free and open access by the Graduate Research at Digital Commons @ Andrews University. It has been accepted for inclusion in Dissertations by an authorized administrator of Digital Commons@ Andrews University. For more information, please contact repository@andrews.edu. 


\section{ABSTRACT}

TEACHER PERCEPTIONS OF THEIR EFFECTIVENESS IN SUPPORTING READING STRATEGIES AS A RESULT OF COLLABORATION WITH A LITERACY COACH

by

Sharon S. Miller

Chair: James A. Tucker 


\section{ABSTRACT OF GRADUATE STUDENT RESEARCH \\ Dissertation}

Andrews University

School of Education

Title: TEACHER PERCEPTIONS OF THEIR EFFECTIVENESS IN SUPPORTING READING STRATEGIES AS A RESULT OF COLLABORATION WITH A LITERACY COACH

Name of researcher: Sharon S. Miller

Name and degree of faculty chair: James A. Tucker, Ph.D.

Date completed: August 2008

\section{Problem}

The poor reading and comprehension skills of many secondary-school students present a challenge for secondary teachers, the majority of whom have no training in the teaching of reading. The increasing expectations of the No Child Left Behind legislature add to the pressures on public educators. Is coaching an effective way to support and encourage secondary content-area teachers to include reading strategies in their daily work with students?

Purpose

The purpose of the study was to examine the literacy coach initiative in two small junior-senior high schools. A further purpose was to closely study the coach and two of 
the teachers with whom the coach interacted, looking for changes in both the use of reading strategies and in teacher perceptions related to the teaching of reading.

\section{Method}

I used purposeful sampling to identify two teachers who were then included in a qualitative case study. The study examined the coaching initiative as perceived by those teachers as they worked with the literacy coach. Data were collected from classroom observations and from interviews with the literacy coach and the two classroom teachers.

\section{Results and Conclusions}

I identified five themes in the data collected across both classrooms and the three teachers interviewed. The themes relating to the coaching initiative were Language and Literacy, Coach as Model, Team-Teaching, Coach as Validator, and Coach Knowledge vs. Personality. I compared the data surrounding these themes to current literature on coaching, especially that from Joyce and Showers, the Reading First initiative, the International Reading Association, and the Reading Apprenticeship initiative.

This study gives a realistic picture of how coaching can work in secondary content-area classrooms. It adds to a growing body of research on coaching as an effective form of professional development. 
Andrews University

School of Education

\title{
TEACHER PERCEPTIONS OF THEIR EFFECTIVENESS IN SUPPORTING READING STRATEGIES AS A RESULT OF COLLABORATION WITH A LITERACY COACH
}

\author{
A Dissertation \\ Presented in Partial Fulfillment \\ of the Requirements for the Degree \\ Doctor of Education
}

by

Sharon S. Miller

June 2008 
(C) Copyright by Sharon S. Miller 2008 All Rights Reserved 


\title{
TEACHER PERCEPTIONS OF THEIR EFFECTIVENESS IN SUPPORTING READING STRATEGIES AS A RESULT OF COLLABORATION WITH A LITERACY COACH
}

\author{
A dissertation \\ presented in partial fulfillment \\ of the requirements for the degree of \\ Doctor of Education
}

by

Sharon S. Miller

APPROVAL BY THE COMMITTEE:

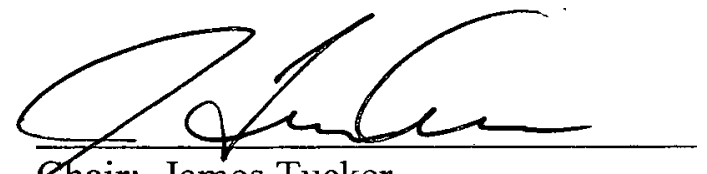

Chair: James Tucker
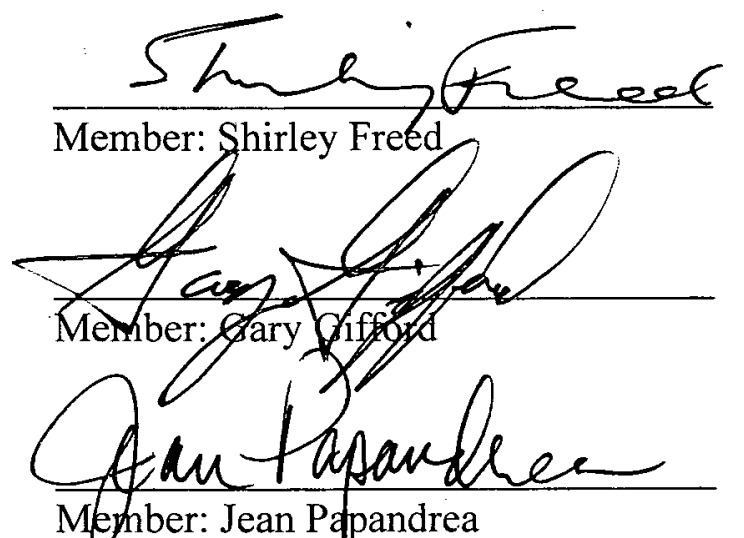

Megnber: Jean Papandrea

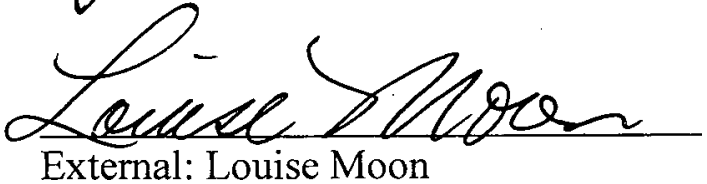

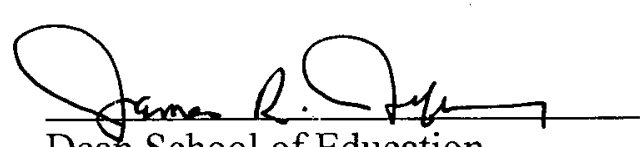

Dean School of Education

James Jeffery

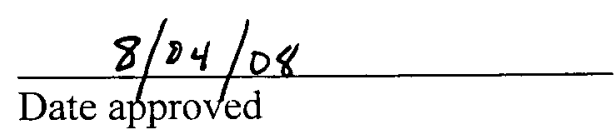


I dedicate this work to the young women in my life: Dana, Stacy, and Megan, my talented and beautiful daughters who make me proud every day; Emilee, Baylie, Kaycie, and Hannah who have the world at their feet and the stars at their fingertips; and all those students who watched me when I knew and when I did not know. I pray that my passion for learning and for education has given you the courage to aim high and fight tirelessly for the best. 


\section{TABLE OF CONTENTS}

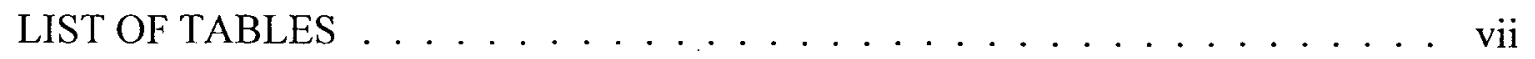

Chapter

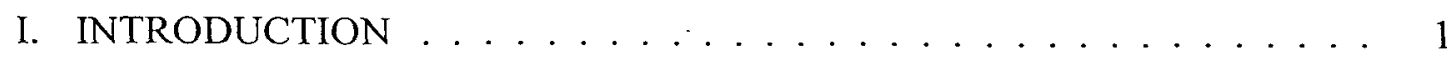

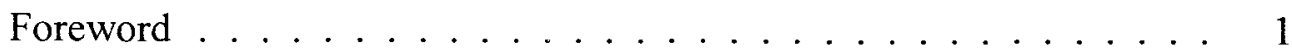

Background of the Problem . . . . . . . . . . . . . 2

Statement of the Problem . . . . . . . . . . . . . . 3

Purpose of the Study .................. . . . 4

Significance of the Study . . . . . . . . . . . . . . . . 4

Research Questions . . . . . . . . . . . . . . . 6

General Method . . . . . . . . . . . . . . . . 6 6

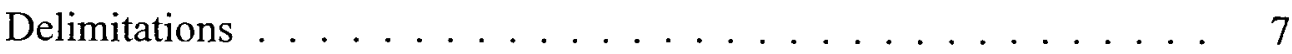

Limitations . . . . . . . . . . . . . . . . . . . . . 7

Definitions of Terms .................. 7

Summary . . . . . . . . . . . . . . . . . . 8

Organization of the Study . . . . . . . . . . . . . 9

II. LITERATURE REVIEW . . . . . . . . . . . . . . . . . . 10

Introduction . . . . . . . . . . . . . . 10

The History of Coaching in Education . . . . . . . . . . . 11

Literacy Coaching. . . . . . . . . . . . . . . . . 13

Coaching as Professional Development. . . . . . . . . . . 15

The Reading Specialist as Literacy Coach . . . . . . . . . . . . . 18

Reading Apprenticeship: A Framework for Teaching Reading

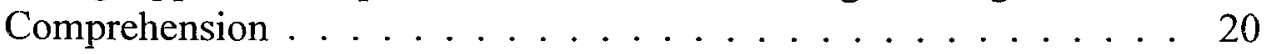

Summary of the Literature . . . . . . . . . . . . 23

III. METHODOLOGY . . . . . . . . . . . . . . . 25

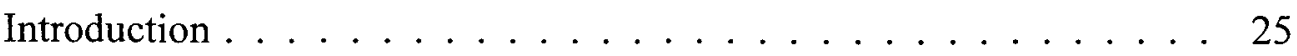

Research Design. . . . . . . . . . . . . . 25

Context of the Study . . . . . . . . . . . . . . 27

Purposeful Sampling Process . . . . . . . . . . . . . . . . 29

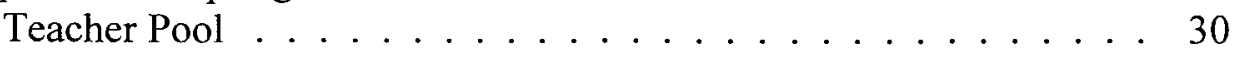

Coach's Data ..................... 30 
Building Administrators' Perceptions. . . . . . . . . . . . 31

Teacher Surveys. . . . . . . . . . . . . . . . . . . 32

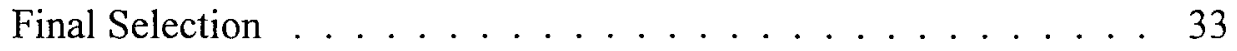

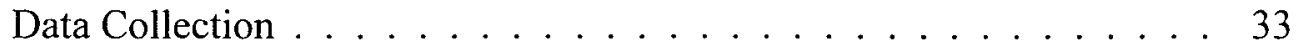

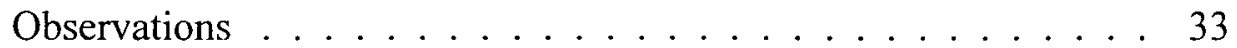

Classroom Artifacts . . . . . . . . . . . . . . . 34

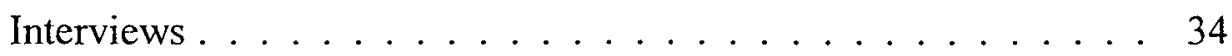

Literacy Coach Interviews . . . . . . . . . . . . . . . . 35

Teacher Interviews . . . . . . . . . . . . . . 35

Ancillary Activities . . . . . . . . . . . . . . . . 35

Data Analysis ............................ 36

Representation of Data . . . . . . . . . . . . . . . 37

Narrative Format . . . . . . . . . . . . . 37

Found Poetry . . . . . . . . . . . . . . . . 39

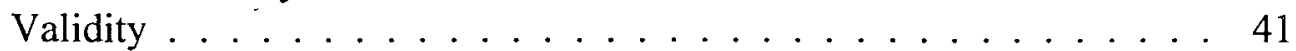

Generalizability ......................... 42

Ethical Considerations . . . . . . . . . . . . . . 44

IV. CLASSROOM OBSERVATIONS AND THEME ANALYSIS . . . . . . . 46

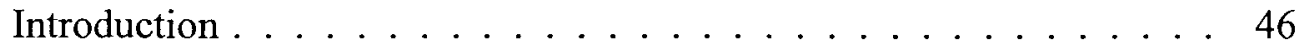

The Classroom of Mr. Stine: The Diary Project . . . . . . . . . . . 46

The Classroom of Mrs. James: English or Reading? . . . . . . . . . . 61

Emergent Themes From Two Classrooms . . . . . . . . . . . . 75

Language and Literacy Theme . . . . . . . . . . . . 77

Coach as a Model . . . . . . . . . . . . . . . . . . . . 80

Team-Teaching . . . . . . . . . . . . . . . . 84

Coach as Validator . . . . . . . . . . . . . . . . . . . . . 89

Coach: Knowledge vs. Personality . . . . . . . . . . . . . . 93

V. RESULTS, CONCLUSIONS, AND RECOMMENDATIONS . . . . . . . 100

Introduction and Purpose $\ldots \ldots \ldots \ldots$. . . . . . . . . 100

Methodology . . . . . . . . . . . . . . . . . 101

Results and Discussion . . . . . . . . . . . . . . . . 102

Literacy Strategies and Teaching Practices . . . . . . . . . . . 102

Teachers' Feelings About Literacy Work. . . . . . . . . . . . 107

How Teachers and the Coach Perceive Their Relationships . . . . . 110

Conclusions . . . . . . . . . . . . . . . . 113

Recommendations. . . . . . . . . . . . . . . 114

For Literacy Coaches . . . . . . . . . . . . . . . . . . . 114

For Teachers. . . . . . . . . . . . . . . . . . 116

For Administrators . . . . . . . . . . . . . . . . . . 118

For Researchers . . . . . . . . . . . . . . . . . . . . . . . 120 
Appendix

A. LITERACY COACH DESCRIPTION . . . . . . . . . . . . . 123

B. COACH INTERVIEW QUESTIONS. . . . . . . . . . . . . 126

C. TEACHER INTERVIEW QUESTIONS . . . . . . . . . . . 128

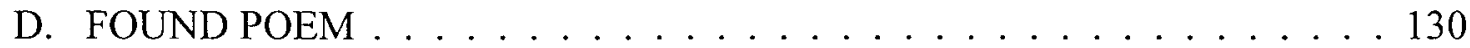

E. LETTER TO SCHOOL BOARD MEMBERS . . . . . . . . . . . 133

F. REQUEST LETTER TO PRINCIPAL . . . . . . . . . . . . . . . . 135

G. ANDREWS UNIVERSITY APPLICATION FOR APPROVAL . . . . . . 138

REFERENCE LIST . . . . . . . . . . . . . . . . . . 141

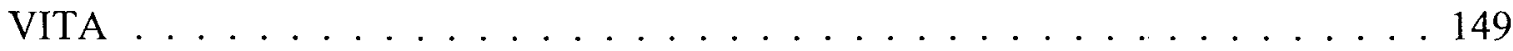




\section{LIST OF TABLES}

1. Structural Corroboration . . . . . . . . . . . . . . . . 43

2. Value of Language and Literacy Activities . . . . . . . . . . . . . . . 79

3. Coach as a Model . . . . . . . . . . . . . . . . . . . . 83

4. Team-teaching. . . . . . . . . . . . . . . . . . 87

5. Coach as Validator . . . . . . . . . . . . . . . . . . . . 92

6. Coach: Knowledge vs. Personality . . . . . . . . . . . . . . . . . . . 98 


\section{CHAPTER ONE}

\section{INTRODUCTION}

\section{Foreword}

For a number of years the education provided by the public schools in America has come under serious internal attack. Reports like $A$ Nation at Risk (1983) and The National Assessment of Educational Progress (NAEP) (National Center for Education Statistics, 2001) have highlighted the ineffectiveness of public education and educators. The latest federal legislation, No Child Left Behind (NCLB) of 2001, has tackled the issue on several fronts. NCLB looks at student attendance, graduation, and dropout rates as well as achievement in math and reading. By requiring all states to design their own high standards for student achievement (or give up access to federal monies for education), this law has placed never-before-seen pressure on states to show performance improvement (Knight, 2005). This pressure on states, of course, results in pressure on local school districts and eventually on individual schools to raise student performance. It has forced educators at all levels to look at what and how students are learning; in the past the focus seemed to be more on content and how teachers were teaching (Cobb, 2005). In this current examination of student learning at all grade levels, one thing becomes crystal clear: Reading is the most important skill that students learn. According to G. R. Lyon (1998), speaking to the U.S. Congressional Committee on Labor and Human Resources, reading opens the doors to all other learning, and not reading, or being 
unable to read or read well, severely limits student achievement in all areas. Poor reading skills discourage students from trying to learn and often result in discipline issues, poor attendance, and/or failure to complete schooling. Leaders of the many initiatives designed to assist schools in meeting the requirements of NCLB quickly embraced the need for enhanced reading instruction for students at all levels.

\section{Background of the Problem}

The problem of improving the reading (and thus learning) skills of students is twofold: First, reading is taught in the primary grades; students learn to read and then they read to learn. From Grade 4 onward, few schools teach reading per se. Just when the reading load increases dramatically, no corresponding reading support is provided (Bauman \& Duffy, 1997). So, we can improve the reading instruction at the primary levels and, eventually, that will translate to better readers in middle and secondary schools. But, what do we do for the 10 or so years until these, hopefully, well-prepared readers reach the higher grades? And what do we do to continue to support the students who simply do not become good readers by third or fourth grade when the content reading hits hard? With the exception of the rare reading teacher who has survived budget cuts at those levels, middle and secondary teachers do not see themselves as reading teachers. Secondary teachers teach content; they are experts in their content areas (Allen, 2000), and few even have a reading course in their own educational backgrounds. Plus, they are not interested in teaching reading - they see reading instruction as taking time from their content (Hall, 2004; Sturtevant, 2002) and, besides, no one likes to try to do something that he/she is not trained to do. 
Second, typical professional development at the intermediate and secondary levels is not effective in changing the behavior of teachers. The traditional "sit and git" method of in-service training simply does not stick (International Reading Association [IRA], 2004; Killion, 2003; Showers, 1985). Teachers are usually willing to sit passively through professionally designed and led workshops, but they seldom have the means to connect the material with what they do back in their classrooms when they return. So, they seldom integrate new learning into their behaviors. There is little time to do so and even less motivation. Graduate work and the extensive professional development, now required by most states, have much the same lack of effect. There is simply no way for teachers to smoothly move what they are learning into practice. Finally, teachers' daily work becomes automatic and new learning and behaviors must be practiced to become part of the repertoire; in fact, Joyce and Showers (1995) estimate that teachers need to practice a new strategy 20 to 25 times before it becomes automatic. Traditional professional development includes no method to develop automaticity and, therefore, is typically ineffective.

\section{Statement of the Problem}

Countryside School District (CSSD), where I have been employed for over 25 years, is a small rural public school district in Pennsylvania. Like all school districts in

the state, CSSD is striving to meet the demands of NCLB; that means raising the percentage of students who read and do math (and, starting in 2009 , science) proficiently on the high-stakes state test incrementally each year toward the goal of $100 \%$ proficiency by the year 2014 . 
As a district, we do fairly well in meeting the reading standards through the elementary years. But, by the time CSSD students reach junior high school, their overall interest in reading and their reading scores decline. Teachers at the junior and senior high levels lament the fact that many students are poor readers and that they either cannot or do not read textbook material. This combined lack of reading skills and poor comprehension skills presents a conundrum to CSSD secondary teachers, the majority of whom have no training in the teaching of reading.

\section{Purpose of the Study}

CSSD has hired a literacy coach to work in its two smaller high schools. The coach's role is to work with teachers of students in Grades 7 through 12 in an effort to improve those students' reading comprehension. She provides professional development by coaching secondary-content-area teachers as they learn and practice skills and strategies that are new to them. The purpose of this study is to determine these secondary teachers' feelings and beliefs about their own effectiveness in teaching literacy skills as a result of working with the literacy coach.

\section{Significance of the Study}

A study of the use of a literacy coach in rural schools is important for several reasons. First, full-time literacy coaching is an expensive form of professional development and a fairly innovative concept. In CSSD, budget constraints typically limit staffing to the bare essentials and the cost of this position may be questioned by future administrators and school board members. Additionally, as Hall (2004) notes, funding and the legitimacy of the position go hand-in-hand; coaching needs funding to ensure 
longevity and, thus, long-term benefits. Teachers need to see a long-term commitment to understand that this is a valued and legitimate source of professional development.

Second, achievement data showing the value of the position may be critical to its retention and to the possibility for the development of future coaching positions. This data, however, may not be obvious especially in the first few years of the initiative.

Currently the CSSD coach is in her second year of the program; she was originally hired to work with $7^{\text {th }}$ - and $8^{\text {th }}$-grade students in two of the three district juniorsenior high schools. The $8^{\text {th }}$-grade spring 2006 state reading scores improved slightly from the previous year in both schools; $8^{\text {th }}$-grade math scores improved significantly in one school and declined in the other. But students are tested in only $7^{\text {th }}, 8^{\text {th }}$, and $11^{\text {th }}$ grades, and 2006 was the first year for $7^{\text {th }}$-grade testing. In addition, the state anchor material was revised for 2007. So, it will likely take several more years to see a solid relationship between the work of the literacy coach and the test scores.

Furthermore, research on the effectiveness of an initiative, especially one as dramatic and expensive as the hiring of a full-time literacy coach, is good professional practice. In CSSD and, I believe, in education in general, we do too little examination of initiatives. Especially in this time of increased pressure for student academic performance, we begin one new program after another with very little follow-up and, consequently, even less data on what is working. Careful study of the effectiveness of the literacy coaching initiative is necessary.

Finally, little research has been conducted nationally on the effectiveness of the coaching-model of professional development. Dole (2004) addresses the need for further study: "What makes an effective reading coach? A research-based answer to this question 
is at least five years away. Right now, little research exists on the use of reading coaches in schools" (p. 468). This research will add to the professional body of knowledge on coaching as it continues to be studied throughout the country.

\section{Research Questions}

The following research questions are central to the purposes of this study:

1. What literacy practices/teaching strategies are the teachers in Countryside School District (CSSD) using with students?

2. How do teachers of Countryside School District (CSSD) feel about the literacy work they are doing?

3. How do teachers and the literacy coach of Countryside School District (CSSD) perceive their relationships with each other?

\section{General Method}

A qualitative case study design was used to examine the coaching initiative as it is perceived by the teachers working with the CSSD literacy coach. Purposeful sampling was used to identify the teachers to be included in the case study. Initially, all teachers who had worked with the coach were surveyed. In addition, the literacy coach's daily logs were studied and the number of times each teacher's name was noted was recorded. Finally, building administrators were interviewed to determine their perceptions concerning the teachers most involved with the coaching initiatives. Data from the three sources were analyzed to determine the teachers who were most responsive to working with the literacy coach. 
Using analysis of the survey data, the coach's tally of classroom teachers, and the administrators' interview information, two teachers were selected for extensive interviews and classroom observations. The teachers chosen were those who appeared to be most open to working with the literacy coach. From a description of literacy strategies provided by the literacy coach, these two teachers were asked to identify those they use and to discuss their comfort level with the usage. Data collected via notes were transcribed, coded for themes, and analyzed. Both interviews with the literacy coach and her notes were studied for themes that were compared to teacher perceptions.

\section{Delimitations}

Since coaching includes, at this time, a broad category of descriptors, responsibilities, and activities, this study will focus on a "literacy coach" model as it is defined and utilized in one school district.

\section{Limitations}

During the period of time since the literacy coach began her duties, other initiatives may have been undertaken and teachers involved may have experienced additional professional development. These additional experiences may have impacted teachers' perceptions about how they address literacy in their classrooms.

\section{Definitions of Terms}

Intermediate Unit (IU) is defined as one of 28 regional-education entities covering the Commonwealth of Pennsylvania; the IUs were created by the state legislature in 1971 to serve as regional service agencies to the public and non-public schools. 
Literacy Coach is defined as an educational specialist who has the knowledge and competence required to address the provision of literacy leadership services for all teachers in specified academic content areas and the supporting resources to assist overall student performance. This is the general description used by the Pennsylvania Department of Education (PDE) in their certification materials.

Pennsylvania Department of Education (PDE) is the statewide body governing public education in Pennsylvania.

Reading Apprenticeship $(R A)$ is a framework for teaching adolescent students how to use metacognitive processes to develop effective strategies for reading comprehension. RA involves extensive modeling by the teacher; thus the "apprenticeship" connection. RA was developed by Ruth Schoenbach and is explained in the book Reading for Understanding, written by Shoenbach, Greenleaf, Cziko, and Hurwitz (1999).

Reading comprehension is the complex cognitive process involving the intentional interaction between reader and text to construct meaning.

\section{Summary}

I have attempted, in this introductory chapter, to present background information relative to the need for coaching as a form of professional development, both in CSSD and on a broader basis. Additionally, I have shown the need for study of this initiative and presented a viable arena in which to conduct a qualitative case study. 


\section{Organization of the Study}

Chapter 2 of this study reviews the literature. That review falls into five categories: the history and recent growth of coaching as a strategic intervention, the work of coaches in the improvement of adolescent literacy, the use of coaching as a model for professional development, the comparison of literacy coaching with the work of the reading specialist, and an explanation of the Reading Apprenticeship framework. Chapter 3 outlines the actual research study and the methodology used. Chapter 4 relates the "stories" of the researcher's experiences in the two classrooms with excerpts from interviews with the teachers and coach interwoven into the descriptions. Also, included is an analysis of the themes that emerged from the observation and interview data. Chapter 5 is a review of the research study, results and discussion, conclusions, and recommendations for future research and practice. 


\section{CHAPTER TWO}

\section{LITERATURE REVIEW}

\section{Introduction}

No Child Left Behind legislation has dramatically impacted American public schools. Although the legislation has become a source for much political comment, there is increasing consensus that education in the United States needs to improve. "Whatever side of the argument you choose, there is no denying that literacy instruction in U.S. schools is changing" (Cobb, 2005, p. 472). "The idea that all children can reach challenging standards, once a fervent hope, is now standard policy" (Neufeld \& Roper, 2003, p. iii). Moreover, the law is based on some very critical national needs. Elizabeth Sturtevant, in the 2002 Alliance for Excellent Education report, says,

Never in this country's history has the need for an educated, literate citizenry been so critical. The increasing complexity of rapid globalization demands a workforce that is skilled in reading, communications, and mathematics. The ability to maintain a growing economy depends on the availability of educated, productive workers. A democratic society requires knowledgeable and involved citizens. (p. 1)

Large amounts of private funding and tax dollars now flow.into the study of educational reform at all levels with the agreement being that reading skills are the basis for all learning. Allen (2000), in an ASCD Curriculum Update, says, "Weak reading comprehension, rather than an outright inability to read, is the main affliction of most struggling readers in middle schools and high schools" (p. 2). As the requirements for student proficiency become more and more stringent (in the legislation's requirement to 
reach $100 \%$ proficiency by 2014), school administrators search for creative ways to help students understand (read and comprehend) material taught.

Increasingly, the literature on educational reform describes some form of coaching as one promising strategy for improved literacy (Hall, 2004; Killion, 2003;

Neufeld \& Roper, 2003). What is this coaching and where did the idea come from? How does coaching fit into the realm of professional development? In other words, can and does coaching improve teacher practice? How does coaching interface with other forms of literacy instruction that are already in place in our school buildings? Finally, and most importantly, does coaching teachers have the potential to improve student literacy and, if so, what are the strategies and skills most necessary for coaches to use in order to make that happen?

\section{The History of Coaching in Education}

The educational literature of the 1980s is prolific with the work of Beverly Showers and Bruce Joyce, who are recognized as the "parents" of the term coaching as it is related to educational innovation. Certainly teachers have been mentoring each other, formally and informally, since the beginnings of formal education in America, but Joyce and Showers made the connection to athletics when they used the term coach. In a 1982 article in Educational Leadership, the two actually interviewed a football coach to make crystal clear the connections between coaching athletes for the purpose of improving performance and coaching as a form of professional development for improvement of instruction. Their conclusions after the interview form the basis for many of their subsequent writings on coaching: 
Perhaps the most striking difference in training athletes and teachers is their initial assumptions. Athletes do not believe mastery will be achieved quickly or easily. They understand that enormous effort results in small increments of change. We, on the other hand, have often behaved as though teaching skills were so easily acquired that a simple presentation, one-day workshop, or single videotaped demonstration were sufficient to ensure successful classroom performance... . Learning to use an inductive strategy for the learning of concepts is probably at least as difficult as learning to throw a block properly. (Joyce \& Showers, 1982, p. 9)

Although Joyce and Showers continued to revise their specific advice on how to train and use the coaching model throughout the 1990s and into this century, they have never wavered from the central theme that "transfer of skills and strategies foreign to the teacher's existing repertoire requires more substantial training than the training we typically allot to such enterprises" (Showers, 1985, p. 44).

Teachers coaching teachers turns up in the literature with a variety of titles. Peer coaching is probably the most common term used. Both Neubert and Bratton (1987) and Moffet, St. John, and Isken (1987) describe peer coaches in a one-on-one relationship in which the coach is the more experienced teacher who works to support a newer teacher. Neubert and Bratton (1987) call their model "team coaching because it resembles team teaching. That is, the coach and the teachers together plan, execute, and evaluate the lesson" (p. 30). Krovetz and Cohick (1993) describe the peer coach as someone who "facilitates early trials with the model by providing support" and "helps the teacher adapt the teaching model to the special needs of the particular students involved" (p. 334). Joyce and Showers (1995) talk about "peer-coaching study teams" (p. 123) who collaborate and learn from one another in on-going, year-long efforts.

In their 2003 synthesis of the literature on peer coaching, Wong and Nicotera note that "the use of effective professional development strategies to improve the quality of teaching has become a critical aspect of school improvement initiatives across states" ( $p$. 
1). Continuing their analysis, they say that "variations of the term peer coaching appear in the literature, such as technical coaching, team coaching, collegial coaching, cognitive coaching, and challenge coaching" but "all the programs use peers to achieve the goal of improving the teaching and learning process" (p. 2).

In recent years, with the near frenzy to improve student performance, organizations outside of the public schools have assumed a role in school improvement initiatives. In some cases, higher education has become deeply involved with K-12 schools surrounding their campuses. The University of Kansas (KU) is one such example; its Center for Research on Learning (KU-CRL) and the program director, Jim Knight, have been training coaches and placing them in a number of Kansas schools including those in Topeka, Kansas (Knight, 2004a). KU-CRL calls its coaches "instructional coaches," and the center has developed a structured training process and heavily uses action research to follow the effectiveness of their coaches. Knight (2004a) defines an instructional coach as "an on-site professional developer who teaches educators how to use proven teaching methods" (p. 32). In the Journal of Staff Development, Knight (2004a) notes that "an instructional coach's main task is to help teachers see how research-validated practices offer useful solutions to the problems teachers face" (p. 33). Although Knight says in the same article that "coaches have to be outstanding teachers" (p. 34), this model appears to place coaches more in a role of expert and less in the role of peer.

\section{Literacy Coaching}

The focus of much school improvement is literacy. Reports such as Reading First (U.S. Department of Education, 2002) and Reading Next (Biancarosa \& Snow, 2006) 
provide the research base and instructional framework for how to teach reading and writing to all students of all ages. Sturtevant (2002) says, "We know that it is possible to teach all of our middle and high school students to read and comprehend demanding texts and other informational resources" (p. 1). The question now becomes how to re-train already practicing teachers in how to teach literacy skills in content area classrooms. "Our teachers must be skilled enough to turn all children into competent readers and writers" (Lyons \& Pinnell, 2001, p. ix).

According to Silverman (2006), "Skilled readers emerge from classrooms where effective reading strategies in specific content areas are taught and practiced" (p. 70). For many students, just providing the reading material is not sufficient; because content area reading is unique and often complex, teachers must learn comprehension strategies to teach their students. Hall (2004) notes that "literacy coaching may be a way to help improve student literacy and reduce dropout rates" (p. 3). Veteran and inexperienced teachers, not trained to support literacy, will need assistance in a variety of ways. "The most challenging aspect of being a literacy coach is creating an environment in which highly experienced content area teachers consider ways to enhance their students' use of reading skills" (Sandmeier, 2005, p. 3). Schachter (2006) further notes, "Teachers will likely need professional development and help in finding quality texts that match their student levels" (p. 38). Clearly having a literacy coach integrally involved in a middle- or high-school setting requires some new ways of thinking about student instruction.

"Key players in the change process are literacy coaches-master teachers who provide essential leadership for the school's overall literacy program" (Sturtevant, 2002, p. 1). These are coaches working with all teachers while keeping in clear view the overall 
literacy goals and needs of a school or district. Neufeld and Roper (2003) note that "districts are recognizing that enabling all students to learn at high levels requires professional development on a large scale and a new way of delivering it" (p. iii). The literacy coach is the teacher-trainer who has highly specialized skills in all manner of literacy strategies, including the teaching of reading.

\section{Coaching as Professional Development}

In their 1995 book, Student Achievement Through Staff Development, Joyce and Showers draw three conclusions about staff development programs, all based on their own research and the research of others:

First, regardless of who initiates a training program, participants must have sufficient opportunity to develop skill that they can eventually practice in classroom settings. Second, if the content of training is new to trainees, training will have to be more extensive than for substance that is relatively familiar. Third, if transfer of training is the objective, training must include the facilitation and structure for collaborative relationships that enable teachers to solve the implementation problems. (p. 113)

Later in the same chapter, the authors go on to elaborate on how peer-coaching and total school coaching teams can facilitate school improvement efforts and, ultimately, student achievement. Coaches provide the opportunity for skill development and reflection on those efforts that is so critical in promoting real change efforts. The collegiality gives teachers the support and positive reinforcement necessary to keep them moving forward when it would be easier to revert to previous practice. "Teachers learn from each other in the process of planning instruction, developing the materials to support it, watching each other work with students, and thinking together about the impact of their behavior on the learning of their students" (p. 125). 
Guskey, in a 2003 synthesis of the most effective characteristics of professional development, notes that "helping teachers to understand more deeply the content they teach and the ways students learn that content appears to be a vital dimension of effective professional development" (p. 9). In addition, he says that the "promotion of collegiality and collaborative exchange" (2003, p. 10) is consistently noted in the literature. While Guskey calls for insistence on student performance as the criteria by which the effectiveness of professional development is judged, these characteristics found in his current synthesis mirror those of Joyce and Showers.

The International Reading Association (IRA), highly respected for its research and support of reading initiatives $\mathrm{K}-12$, has recently taken a strong stance in favor of coaching as a model for both professional development and improved student literacy. "The International Reading Association continues to promote the reading coach model as a professional development approach with vast potential to improve student reading proficiency in elementary, middle, and high school" (Roller, 2006, p. 1). This follows a 2004 position statement, The Role and Qualifications of the Reading Coach in the United States, which said, "Specifically, there is evidence that one-shot, workshop-oriented professional development efforts do not result in changes in classroom practice or in student learning" (IRA, 2004, p. 2). The IRAs 2006 Standards for Middle and High School Literacy Coaches are a "how-to" for anyone approaching the adoption of the coaching model, and in the introduction state, "Literacy coaching - a form of highly targeted professional development-is a particularly potent vehicle for improving reading skills" (p. 3). 
Coaching as professional development can certainly provide the on-going teacher support that is so critical after the initial dissemination of new materials, ideas, and/or instructional strategies. But it can also meet individual and specific school district, building, and even teacher needs that more generalized, whole-group workshops cannot. Neufeld and Roper (2003) note that "coaching is school-based professional development designed in light of the district's reform agenda and guided by the goal of meeting schools' specific instructional learning needs" (p. 4). Likewise, Hall (2004), in the Carnegie Reporter, reflects that "coaches are an answer to a district's need to provide ongoing professional development for teachers in specific content areas" (p. 1). Writing for The School Administrator, Diamond (2006) says that effective professional development "must be multidimensional, accounting for teacher background, school culture, and the particular needs of adolescents" (p. 13). Coaching, especially using internal staff members, can accomplish the goals of personalization as well as supporting teacher and student learning.

The 2006 Standards for Staff Development, published by the National Staff Development Council, focuses on student learning as a measure of staff performance and, in doing so, includes the need for adult learning and collaboration. The NSDC recommends that "the vast majority of educators' professional learning should occur during the school day in collaboration with colleagues" (Resources section, p. 1) and states that in-school coaches could be a part of that plan.

A growing body of research (Neufeld \& Roper, 2003; Rasmussen, 2005; Sturtevant, 2002; Wong \& Nicotera, 2003) substantiates the belief that coaching is an effective form of professional development. It certainly seems to fill the gap that is often 
missing between pre-service education and the growing and increasingly complex body of knowledge about how children of all ages learn. Too often beginning (and veteran) teachers are too busy keeping up with the daily routine to pursue their personal on-going professional development. Unfortunately, the one-shot workshops have little impact because those same teachers come back to their classes with the same daily chores waiting and no extra time to reflect on and practice any strategies they may have learned. "An important part of the literacy coach's role is to offer up-to-date, research-based, professional development. The cornerstone of this is follow-up. Here is where we really see coaching at its finest. Just giving a drive by inservice will not help" (Moxley \& Taylor, 2006, p. 9).

\section{The Reading Specialist as Literacy Coach}

In her 2004 book The Reading Specialist, Rita Bean gives a brief history of the position of the reading specialist in American education. She describes how specialists started out in the 1930s as "supervisors who worked with teachers to improve the reading program" (p. 2) and evolved into teachers of remedial reading whose days were crammed with struggling readers being pulled from the regular classrooms to do supplemental literacy work. With the federal initiatives of the 1960s, reading specialist became "Title I teachers" and, unfortunately, received some negative publicity as the reports of the 1980 s and early 1990s showed U.S. students falling further and further behind. Due to funding cutbacks and disenchantment with the state of reading instruction and remediation, many school districts dramatically decreased their reading specialist numbers during the 1990s; most reading specialists are now found in the primary grades. 
According to Bean (2004), the International Reading Association, the primary professional organization for reading teachers, established a 1995 "commission to investigate the role and status of reading specialists in schools" (p. 6). The commission produced a position paper, Teaching All Children to Read: The Roles of the Reading Specialist (IRA, 2000), in which reading specialists' roles are described in three areas: instruction, assessment, and leadership. In the leadership role, reading teachers are urged to "aid teachers ... play an essential role in supporting individual teachers-especially new teachers ... lead professional development workshops, model strategies or techniques for teachers, and conduct demonstration or collaborative lessons" (p. 2). As early as this 2000 document, there is a strong similarity to later descriptions of how the roles of literacy coaches are now defined.

In 2004 the IRA published another position paper, this one entitled, The Role and Qualifications of the Reading Coach in the United States. This brief publication addresses the importance of the reading coach in professional development and staff support; it clearly delineates characteristics necessary for reading coaches including having been excellent classroom teachers having the skills to work well with adults. As the push to hire coaches increased and districts scrambled to find qualified persons, the IRA stood strongly by the requirement that reading coaches first be certified reading specialists.

Most recently the IRA (2006) published their Standards for Middle and High School Literacy Coaches. This extensive document is really a "how-to" for any school or school administrator anticipating adoption of a coaching model. The IRA describes these standards as 
a set of leadership standards that apply to literacy coaches without regard to the content area in which they are assisting teachers and a set of content area standards that apply to the demands that literacy coaches face when assisting in English language arts, math, science, or social studies. (p. 4)

In each of the four core curriculum areas mentioned, the IRA collaborated with the relevant national curriculum organization to write content standards that meet the particular needs of that area. Consequently, the standards are all-encompassing and give specific direction for the aspiring or fledgling literacy coach regardless of the teacher seeking assistance.

In this document the IRA states that, although the eventual role of the coach is the improvement of student performance, the immediate challenge is to focus on the teachers' learning (p. 44). The authors agree with Guskey that research is necessary to identify student achievement as a result of literacy strategies but says that "waiting for that body of research to be produced before committing to coaching is neither feasible nor wise" (p. 46). The IRA notes that "much can be learned from case studies of coaches" (p. 46) and calls for action research that would "enable the field to learn from the experience of trying out those good ideas" (p. 46).

\section{Reading Apprenticeship: A Framework for Teaching Reading Comprehension}

The Reading Apprenticeship framework evolved from a California initiative between secondary teachers and members of a research and professional development initiative called the Strategic Literacy Initiative (Schoenbach et al., 1999). Working in urban San Francisco schools, the team struggled with the issue of reading-in-the-content area at the middle and secondary levels, particularly at the ninth-grade level where students began to accumulate credits for graduation. Here, where students were expected 
to get serious about academics, poor readers of textbooks and other nonfiction materials quickly hit what Schoenbach et al. (1999) call the "literacy ceiling" (p. 5). In their 1999 book, Reading for Understanding: A Guide to Improving Reading in Middle and High School Classrooms, Schoenbach et al. describe this as "a ceiling that limits what students can hope to achieve both in the classroom and in their lives outside of school" (p. 5).

The California teachers and researchers began to realize that the reading problems of older students frequently result from their lack of effective comprehension skills. Schoenbach et al. (1999) note that "the belief that reading is essentially a process of saying the words rather than actively constructing meaning from texts is widespread among many students" (p. 6). These students simply have never developed the reading stamina and the comprehension skills that good readers have.

A further connection made by the members of the Strategic Literacy Initiative (SLI) was that teachers have the needed reading comprehension skills and that they can give students the opportunity to see how they use them in their reading. In other words, the students should be apprenticed to the teachers, to learn from the teachers' modeling of the reading skills, through explicit practice in the classroom. From this discovery came the core idea of the reading apprenticeship initiative which eventually was trademarked and became the Reading Apprenticeship Framework marketed by the Strategic Planning Initiative thorough the California-based WestEd nonprofit group. Reading Apprenticeship (RA), however, is not a program or a set of materials; it is a framework for teaching reading comprehension skills that includes some comprehension strategies. The framework is disseminated through week-long workshops offered by WestEd and through Schoenbach et al.'s 1999 book. 
The RA framework is based on the idea of meta-cognition or thinking about thinking. Good readers think about what they are reading but also about how they are understanding and reacting to what they are reading. Effective readers realize when they are having trouble comprehending; they stop, go back, and use time-tested strategies to make sense of their reading.

RA is much more than just teaching those reading strategies; teachers must first help students understand and experience the concept of meta-cognition. The RA website describes the work that teachers and students do in this way:

Students work collaboratively to make sense of texts, while simultaneously engaging in a conversation about what constitutes reading and how they are going about $i t$. This metacognitive conversation is carried on both internally, as teacher and students reflect on their own mental processes, and externally, as they share their reading processes, strategies, knowledge resources, motivations, and interactions with, and affective responses to texts. (The Reading Apprenticeship Framework, n.d., 93)

Much of the meta-cognitive work is accomplished through modeling: read-alouds and think-alouds are a major part of the RA classroom. Students need to see how the teacher, an effective reader, approaches text and how he/she makes text connections throughout the reading. These connections may involve prior personal experience, they may involve something or someone in the reader's world, or they may involve a connection to another piece of reading or learning. These are the connections that make reading meaningful and making learning "stick." Poor readers need to be explicitly taught how to make these connections and that is the heart of the RA process.

There is much more detail in the RA framework and companion materials including descriptions of real lessons from RA teachers (e.g., Fielding \& Shoenbach, 2003) and student stories about reading (e.g., Fielding, Schoenback, \& Jordan, 2003). 
Weeklong training sessions for reading teachers and coaches are scheduled regularly throughout the United States and these trainings may be extended so that local teachers have the opportunity to become RA trainers in their school districts.

\section{Summary of the Literature}

This chapter has provided a brief look at the literature surrounding the position of the literacy coach. Coaching in classrooms is a relatively innovative concept and a study of that position requires some background information on several fronts. Understanding what literacy coaching is and from where it has evolved is crucial to the understanding of how the initiative may be perceived by classroom teachers.

The concept of coaching in the academic setting comes from decades of work by Bruce Joyce and Beverly Showers who borrowed the idea from athletics. Referring to the typical workshop-type trainings offered to educators, Joyce and Showers (1982) noted that teachers cannot be expected to simply walk from trainings into their classrooms and put new learning into practice (p. 5). Coaching is the missing link that supports teachers while they practice and perfect new skills. While many other educational researchers have developed coaching models, Joyce and Showers remain the reference point for this concept. Coaching as an effective form of professional development is currently accepted by most educators and is strongly advocated by the National Staff Development Council (2001).

Reading research in the late $20^{\text {th }}$ century culminated in the Reading First initiative (U.S. Department of Education, 2002) and the huge federal grant program that supported the focus on the systematic teaching of reading in public schools. From this program came the term "literacy coach" and the funding for many elementary schools to hire 
literacy coaches. The International Reading Association (IRA) has been the major player in the advocacy for literacy coaches to have reading certification as well as the initiative to shift reading specialists from supporting students to supporting classroom teachers through coaching.

Reading specialists and literacy coaches at the secondary level are less common and focus more on student comprehension of content-area text. Reading Apprenticeship is one framework to assist students and classroom teachers in addressing the challenges of comprehending $21^{\text {st }}$-century reading expectations. 


\section{CHAPTER THREE}

\section{METHODOLOGY}

\section{Introduction}

How can secondary, subject-area teachers develop classroom strategies that both involve and interest the students while simultaneously increasing student comprehension and retention of material to be learned? Is it possible for those very same teachers, trained in math, science, social studies, and other disciplines, to teach their adolescent students to be much better readers and writers? If it is possible, is it practical given the parameters of time and resources of public education? And, most critically, what further training (i.e. professional development) will facilitate this process? My research examines the use of a coaching model to increase the likelihood that all secondary teachers will accept and develop the role of "reading" teacher within their classrooms and disciplines.

Specifically, I look at the ways in which Countryside School District (CSSD) teachers working with the literacy coach believe that their attitudes, beliefs, and practices have changed as a result of that professional relationship.

\section{Research Design}

I used the qualitative case-study approach to examine the literacy-coach initiative in two secondary schools in the district where I am employed as the Supervisor of Curriculum and Instruction. Merriam (1998) notes that "case study is a particularly 
suitable design if you are interested in process" (p. 33). She further elaborates on case study as one form of qualitative research, saying that it "has proven particularly useful for studying educational innovations, for evaluating programs, and for informing policy ( $\mathrm{p}$. 41).

Eisner (1998) describes the value of personal, interactive research as being important for the understanding of the researcher as well as the growth of the educators and the students being studied. "Qualitative inquiry-in this case the study of schools or classrooms - can provide the double advantage of learning about schools and classrooms and learning about individual classrooms and particular teachers in ways that are useful to them" (p. 12).

The reciprocal nature of qualitative research provides a rich learning environment for everyone involved. The learning is based on an immersion in the whole educational setting and, in this instance, assists in developing a continuing understanding of the complex relationships between literacy coaches and teachers as they work through the development of a new literacy program. During my research, I shared, discussed, and analyzed discoveries made with and among the teachers, administrators, and even school board members of this district, making the entire process iterative and beneficial to all involved.

Professional development is not effective until participants, in this case teachers, internalize new learnings and then develop "sufficient skill [to a point] that practice can be sustained in the classroom and transferred into the working repertoires of teachers" (Joyce \& Showers, 1995, p. 117). Ellis (2005) notes that "the practical application of ideas by teachers and students in real-world educational settings represents the best test 
of an idea's staying power" (p. 18). In speaking of educational innovation, Fullan (2001) says that shared vision is a necessary requirement for the sustenance of innovation. Teachers' perceptions, how they think and feel, about their interaction with and their resulting instructional successes as a result of a literacy coach are, then, critical indicators of the possible strength of the program. For this reason, teacher perceptions were the critical piece of this research and were collected in several ways and across several venues.

\section{Context of the Study}

Ward Junior-Senior High School (WHS) is a rather drab and unattractive building located in the center of Countryside School District. Connected to an elementary school, WHS occupies a block right in the center of a small factory town. Years of soot from the nearby factory have grayed the building's bricks and the wooden framing of the windows. The building has an inner-city look with just a fringe of grass between the sidewalks and the outside walls.

Approximately 310 students, 25 teachers, and one administrator attend and work at WHS. Since the town includes several low-rent housing developments and aging homes, this building has the highest percentage of economically disadvantaged students in the school district. Although the student numbers are stable, the dropout and graduation rates and the state test scores are of some concern. At the beginning of the 2006-07 school year, the district leader made some administrative changes that included replacing the lone administrator of WHS with a young, first-year principal. The staff here is also somewhat transitory; the language arts staff has been especially difficult to maintain with turnover in that department annually for the past 5 years. 
Belle Junior-Senior High School (BHS) is a tidy building situated on several acres of green at the edge of a tiny, rural community; this school is 10 miles south of WHS and is situated at the southern end of the school district. The physical setting is picturesque as the school sits on a hill, surrounded on three sides by views of farms and woodland. The only suggestion of intrusion on the bucolic scene is the four-lane interstate highway just west of the school. The school and its grounds appear to be well cared for and maintained.

Approximately 270 students and 24 teachers join a single administrator at BHS from late August through mid-June each year. Both staff and student body are fairly stable, although the past 10 years have seen a number of teacher retirements. The anticipated student growth, as a result of the highway becoming four lanes about 5 years ago, has not materialized. The principal there has also changed in the past 2 years; the former principal moved to a central office position, and the current administrator is a veteran educator who has moved through the ranks to building leadership.

Mrs. Susan Baker is the literacy coach in both WHS and BHS; she is completing her second year in this position. Previously, Mrs. Baker started her career in Countryside School District as an English teacher at BHS. She taught there for 9 years and, during that time, earned a Master's degree in English education and a Reading Specialist certificate from a local university. During this time, Mrs. Baker also earned the respect of her peers and district administration, becoming known as a knowledgeable and effective teacher.

After a hiatus of parenting her young children, Mrs. Baker spent several years as an adjunct instructor teaching Composition I at a local technical college. When the position of literacy coach was created, both WHS and BHS principals called and asked 
her to apply. After some negotiation, Mrs. Baker did apply and was hired for her current position in July 2005. Although a job description was created for the position (Appendix A), Mrs. Baker has had a great deal of freedom in molding the job of literacy coach. Training for the literacy coach has been minimal. Some current books on coaching have been supplied. The primary source of training has been a trainer-oftrainers workshop on Reading Apprenticeship (RA) that Mrs. Baker attended with two professional developers from the local intermediate unit (IU). The RA model and literacy strategies have become the foundational pieces for the coaching initiative in CSSD.

Currently, Mrs. Baker follows an alternate day schedule between her two schools. She has a classroom of her own at WHS and an office off the library at BHS, but most of her time is spent in the classrooms of other teachers. She works with the local intermediate unit charged with providing ancillary educational services to CSSD, as well as a local university to expand her knowledge and resources. Mrs. Baker is currently working on her doctorate in a university weekender program.

\section{Purposeful Sampling Process}

My goal for this research was to identify two teachers who have worked closely with the literacy coach during the short time she has been employed in Countryside School District. I wanted to investigate how the teachers' perceptions of supporting reading instruction had been impacted by their time with the coach in their classrooms. In this section I will explain the process I used to select these two teachers.

I studied information collected from the literacy coach, interviews with the principals and guidance counselors in the two schools, and teacher survey data. My goal, in examining data collected, was to select a teacher from each building who had worked 
with the literacy coach extensively during the three school semesters prior to the research. Since the coaching position was relatively recent in this school district, there may have been some teachers who had little or no exposure to the coaching phenomenon. I wanted to include teachers who had a background and comfort level with the coaching process. In addition, it was my goal to identify teachers who were comfortable and willing to have me conducting research in their classrooms throughout the spring of 2007.

\section{Teacher Pool}

Persons eligible for this study were the 24 teachers who are employed at Belle Junior-Senior High School and the 25 teachers employed at Ward Junior-Senior High School. Both schools are part of a rural public school district, serving about 2,300 students, and both include Grades 7 through 12. In the study, I also included the literacy coach who serves both schools and the principal and guidance counselor of each school.

\section{Coach's Data}

The literacy coach has kept a brief, daily log since the inception of her position in August 2005. In WHS, 18 teachers were mentioned at least once and, in BHS, 23 teachers were mentioned at least one time in the log. I studied this log and noted the number of times that each teacher's name was recorded. I gave no consideration to the reason for the notation; the number of times that each name appeared in the log was simply counted. This data source provided a picture of the scope of interaction between the literacy coach and each teacher. 
At WHS one teacher's name was noted 42 times, almost twice as often as the next most frequently noted. At BHS, two teachers were mentioned 25 and 22 times, seven times more often than the next most frequently noted.

\section{Building Administrators' Perceptions}

I interviewed the principal and the guidance counselor of each school to determine their perceptions of the coaching initiative. I decided to include the guidance counselors in these interviews for two reasons: Neither school has an assistant principal and, therefore, the guidance counselor often interacts with teachers and students in a pseudo-administrative role. Also, both principals are recent additions to their schools, and neither has the background of coaching research and literature that prompted the coach's hiring in the spring of 2005. In addition, the guidance counselors are active throughout the buildings and have many opportunities to observe teacher interactions and to informally assess the success of initiatives.

In verbal interviews, conducted either in person or over the telephone, I asked principals and guidance counselors to discuss how the literacy coach worked with teachers in their buildings and to describe some of those interactions. This discussion was intended to provide me with a basis for determining whether or not the administrators of each building were aware of the depth of interactions between the coach and the teachers.

I then asked each principal and guidance counselor to identify the teacher(s) who he/she felt had been most receptive to the literacy coach's initiatives. Interestingly, in each school, the principal and the guidance counselor, although interviewed separately, mentioned the same two names. In WHS, both named the teacher with the 42 notations in the coach's log and another teacher who had over 20 notations. In BHS, both the 
principal and the guidance counselor named the teacher with the 25 notations and another who had 5 notations in the coach's log.

\section{Teacher Surveys}

All classroom teachers in each school were eligible to participate in a survey to determine their individual levels of concern over the literacy-coaching initiative. Hall's 1986 Stages of Concern questionnaire (SoCQ) (Hall, Hord, George, Stiegelbauer, \& Dirksen, 2006) was used. I explained and administered the SoCQ at faculty meetings held in each school in the early spring of 2007. Teachers were given an overview, both written and oral, of the researcher's proposal; they were also given a copy of the SoCQ with written directions and oral directions. I told teachers that completion of the survey was voluntary and that their names were optional. I also explained that any teacher who was willing to participate in further research by inviting classroom observations and discussions should include his/her name on the survey. Teachers who were uncomfortable or, for whatever reason, unwilling to have me in their classrooms in the spring of 2007 should not include their names on the surveys.

At WHS, 20 teachers completed the survey with 8 teachers including their names. At BHS, 18 teachers completed the survey with 6 including their names. Since the numbers of usable surveys (those with names included) was small (14), I graphed the data manually using the Stages of Concern Quick Scoring Device. Scores were charted for these 14 surveys.

Data from the SoCQ were inconclusive with no clear indication of comfort with the innovation of literacy coaching. However, the four teachers identified by the building 
administrators were among the 14 teachers who wrote their names on the surveys, indicating their willingness to participate in the study.

\section{Final Selection}

Following analysis of the collected data, I selected two teachers, one from each building, and asked each personally if he/she would be willing to open his/her classroom for observation. In each building, I approached the teacher with the highest number of notations in the coach's journal as each was also one of the teachers mentioned by his/her administrator and each had indicated willingness to participate via the survey. After hearing a more in-depth description of the research proposal, each teacher selected agreed to participate and helped me to select classes and times for observations. As the research required the ability to observe the teachers and the coach working together, I also contacted the literacy coach and asked for her input on the observation schedule.

\section{Data Collection}

Once I had identified the two teachers to be included in the study, I collected data during the spring of 2007. Data collected included field notes taken during classroom observations in the classrooms of two teachers; classroom artifacts, including pictures, worksheets, project instructions, and student journal entries; interview notes from interviews conducted with the two teachers and the literacy coach; and artifacts collected from activities outside of the classrooms.

\section{Observations}

In WHS, I conducted classroom observations over a 7-week period in the social studies classroom of Mr. Stine during sophomore U.S. History II classes. The classes met 
for 42 minutes, and two back-to-back classes were observed. Mr. Stine is an 18-year veteran whose entire career has been in WHS.

In BHS, I conducted classroom observations over a 5-week time span. The teacher, Mrs. James, is a 10-year Language Arts teacher who has taught in this building for 7 years. The class observed was a seventh-grade English class taught in an 84-minute block of time. In addition, I returned in the fall of 2007 to observe this class, now eighthgraders, in a reading class also taught by Mrs. James. This was the first year for juniorhigh reading classes in CSSD.

I wrote field notes in the classrooms, trying to collect as much student and teacher conversation, description, and atmosphere as I possibly could. I added thoughts and questions during the observations and afterward as I read, typed, and reread the notes.

\section{Classroom Artifacts}

I collected classroom artifacts whenever they were available without disrupting instruction. Artifacts include handouts, assignments, and, in one case, copies of student work. I also took pictures of both classrooms.

\section{Interviews}

Personal interviews are one method of collecting data and are especially useful for the collection of perceptual data. Merriam (1998) says, "Interviewing is necessary when we cannot observe behavior, feelings, or how people interpret the world around them. It is also necessary to interview when we are interested in past events that are impossible to replicate" (p. 72). In this case, I was observing the coach-teacher relationship, but I also wanted to gather additional information about teacher feelings that may not have been 
obvious and about events that happened in additional classroom settings that I did not observe.

\section{Literacy Coach Interviews}

I interviewed the literacy coach one time formally, using prepared questions (Appendix B). In addition, I held numerous informal conversations with the coach. Most of these conversations occurred outside of the classrooms and, immediately after, I wrote down the details of the conversations. Short conversations held within the classroom were included in field notes.

\section{Teacher Interviews}

Mr. Stine and Mrs. James each participated in a formal interview, answering prepared questions (Appendix C). As I had questions about classroom activity, I took advantage of time before and after my classroom observations for informal conversation.

\section{Ancillary Activities}

In Mr. Stine's classroom, due to the nature of the subject matter, I became involved in several activities that were conducted outside of the classroom. I attended an academic fair where students from this class displayed their class journals and other materials. I also attended an assembly and a dinner that evolved from the project conducted in Mr. Stine's classroom. In addition, I helped to chaperone a field trip designed as a culmination activity for these students. I collected artifacts from these experiences.

During the time I conducted research, both Mrs. Baker and Mrs. James were also involved in meetings to develop junior-high reading courses in CSSD. As the course was 
directly related to the district initiative to focus on reading across the junior-high curriculum, I also included minutes of the reading meetings in my research materials.

\section{Data Analysis}

I interviewed teachers and, among other things, asked them to identify literacy strategies they used before working with the coach. Teachers were also asked to identify those they now use and to discuss their comfort level with the usage. I studied the notes kept by the literacy coach and data from several interviews with the coach, looking for themes that I compared to teacher perceptions. I also had a number of informal conversations with the coach and teachers as I spent time with them before and after classes and, in the case of Mr. Stine, while on a field trip.

I spent about 10 hours, over the period of several months, in each of the classrooms and, while there, tried to absorb as much of the culture of the classrooms as I could. I took notes on the classroom discussions and conversations that occurred around me. I also wrote detailed descriptions of what I saw and heard. I tried to find evidence in the classrooms that linked to and supported my conversations with the three teachers.

Observation data collected via field notes were typed, coded for themes, and analyzed. My review of the literature prior to completing classroom observations and previous conversations with the literacy coach had given me some idea of what I might see in the classrooms. For instance, I expected to see the teacher as the authority in subject matter and the coach fostering related literacy activities. I thought; and certainly hoped, that I would see some connections being formed between each teacher and the coach. 
As I identified possible themes, I organized supporting data from classroom observations, from interviews with the two teachers, and from interviews with the literacy coach in tables for each. This helped me to assess the strength of each theme. Were there data in each category of my research, classroom observations, and interviews to support the theme? Was there support for the theme in the literature? Once I had determined the primary themes, I began to organize my writing in a way that would be clear to readers of my research.

\section{Representation of Data}

This scholarly document must represent a clear picture of what I have seen, heard, and experienced in the process of conducting research and collecting data. The picture that I present must be accurate and must enable the reader to understand my work well enough to replicate any part of it. Only by clear representation can individual data grow into bodies of solid educational research.

\section{Narrative Format}

My goal as a researcher was to represent my work in a way that facilitates understanding for my readers. Schwandt (1999), in speaking of understanding, says, "We both start and end our efforts to answer the question 'What do we make of this?' in our best grasp, our best account, of ourselves as agents in the world" (p. 453). I chose to represent the data I collected in narrative or "story" form using first person and linear time. Merriam (1998) notes that it is becoming commonplace for qualitative research to contain a section on the personal experience of the researcher. 
Tierney (1997), speaking of the various ways to use time and voice in narrative research, describes the use of "I" as follows:

The author is a stable figure who exists within the story. . . The authors employ firstperson narrator to move the events of the text along to a conclusion and to highlight that the author is involved in the construction of the text. The author is seen as a single narrator and as a consistent figure within the action. (p. 26)

As a veteran educator in the district where I conducted this research, I have a history, biases, and vested interests. Eisner (1998) says, "Our experience of the world is a function not only of its features, but of what we bring to them. We are always in a constructive position. We make our experience, not simply have it" (p. 60). I recognized that I was a part of the research I conducted, and my perceptions of the work of Mrs. Baker, Mr. Stine, and Mrs. James influenced my findings. Yet, my perceptions were legitimate as I brought valuable years of experience to the research.

I also chose to convey the activities in the two classrooms in, generally, linear time, described by Tierney (1997) as "chronologically, so that the reader discovers a beginning, a middle, and an end" (p. 28). In both Mr. Stine's and Mrs. James's classrooms, stories unfolded in the time that I was there. In both cases, I was part of those stories and my retelling makes the most sense to me in a linear time frame. Barone and Eisner (1997) state that "meaning is achieved as portions of the world are construed and organized, and the representation of that world is composed into a telling document" ( $p$. 89). I believed that a document organized in a narrative form related the stories of these two classrooms most clearly. 


\section{Found Poetry}

I was first introduced to poetry as a form of expression of research findings in a qualitative research course with Dr. Shirley Freed of Andrews University. Dr. Freed provided examples of found poetry in both her own work and the work of others. I was fascinated with this alternative form of expressing research and used a found poem to summarize the data from my final project for that qualitative course (Appendix D). This experience led me to consider using poetry as an avenue for the expression of my dissertation data.

In speaking of alternative forms of research representation, Eisner (1997b) says, "Poetry was invented to say what words can never say. Poetry transcends the limits of language and evokes what cannot be articulated" (p. 5). Corrine Glesne (1997) further analyzes the value of alternate forms of representation, noting that "art forms, such as poetry, provide tacit experiences for readers. Interpretation requires engagement in ways that go beyond cognition" (p. 217). A strong advocate of experimental forms of writing, Richardson (2005) believes that "settling words together in new configurations lets us hear, see, and feel the world in new dimensions. Poetry is thus a practical and powerful method for analyzing social worlds" (p. 522).

As I sat in the two classrooms in Countryside School District and watched, listened, and attempted to record the data, I realized that much of what was going on around me was of the social and emotional realm. True, facts were being conveyed, strategies were being used, teachers were teaching, and students were learning, but life was being played out in these classrooms. And, in the moments of greatest educational value, students, teachers, and researcher alike were caught up in strong emotions. 
Descriptive prose seemed inadequate to describe all that I could see, hear, and feel in those classrooms.

In working with the literacy coach to support the use of reading strategies in content-area classrooms, I purchased a workbook, 50 Content Area Strategies for Adolescent Literacy (Fisher, Brozo, Frey, \& Ivey, 2006), for each of the teachers in WHS and BHS. While in the midst of trying to make sense of the classroom data I had collected, I received a call from the literacy coach. "Look at strategy number 10 !" she said. Sure enough, "strategy number 10 " on the $28^{\text {th }}$ page of the workbook is "Found Poems." The strategy is introduced with, "Language has powerful influence on learning concepts. Found poems (Hobgood, 1998) encourage students to discover how authors use specific words and images to capture the essence of their writing and the information they would like to convey to the reader" (p. 28). Hobgood (1998), in an article in Voices from the Middle, says that found poems "represent the crystallized meaning that stays with the reader long after the initial reading is over" (p. 29).

The fact that found poetry was introduced to me in my first experience with qualitative research, one in which I first began the investigation of literacy coaching, and then came back at me several years later as I simultaneously worked with the literacycoaching initiative in my schools and struggled to find a suitable format in which to situate my dissertation research nudged me to re-examine this form of representing my thoughts. I realized that poetry is an avenue for understanding as well as an avenue for expression. Therefore, I wrote poems from the words, thoughts, and perceptions that I found in the two classrooms I visited. Through the poems, I attempted to both synthesize 
the classroom experiences and give the reader a deeper understanding of the teachers, students, and classroom experiences. Schwandt (1999) argues,

If there is a kind of cognitive power to be had by doing qualitative inquiry, then it is the power of refining our ordinary understanding of our practices of teaching, healing, managing, learning, and so forth, rather than any leap out of the lived reality of those practices. (p. 543)

Through poetry, I tried to refine the readers' understanding of what was happening in the classrooms of Mrs. James and Mr. Stine.

\section{Validity}

Qualitative research places the researcher in the midst of the research. Rossman and Rallis (2003) note, "The researcher is involved, face-to-face, with the participants in the study. ... Data are filtered through the researcher's own unique ways of seeing the world--his lens or worldview" (p. 26). In my case, I was sitting in two classrooms in the school district in which I work. I was observing and interviewing teachers whom I know and care about. It should be no secret that I have the best interests of the students and teachers of this district at heart and, thus, want the coaching initiative to work and work well. The question I faced early on was how to make sure that the data I collected and the interpretations that I made of that data were as valid as possible.

Elliot Eisner (1998) makes three very important statements about validity. First, he notes that "reality "as it really is"" is "impossible to attain" and that, no matter the kind of research or the strength of the design, there will always be fallibilities (p. 109). In qualitative research, says Eisner, "the scope is wide for people to see what they choose to see, or to interpret what they see according to their own theoretical lights" (p. 110). Eisner uses the term "structural corroboration" to describe a process of collecting 
multiple types of related data to build confidence in the evidence and arguments presented (p. 110). Finally, Eisner concludes by noting that it is the reader who ultimately decides if the meaning of the research is clear, relevant, and/or useful and that some of this decision-making must be based on the particular voice of the writer.

I used structural corroboration to verify information as it was collected and, thus, increase the validity of my findings. As I read and reread my observation notes and thoughts, I continually compared them to conversations I had with the teachers and the coach. In formal interviews, I referred again to my observations and informal conversations. As I talked to the coach, I confirmed my observations and perceptions of both classroom activity and teacher behaviors. As I talked to the teachers, I used the same strategies, this time referring to things that the coach did.

In this process, I moved back and forth between these three modes of data collection as information and themes were identified and questions arose. During this iterative process, I worked with the teachers and coach as we all attempted to identify the impact of the literacy-coach initiative. Table 1 shows how I triangulated the data using my research questions and the data sources.

\section{Generalizability}

The value of research is that we can learn from it and then, hopefully, apply what we learn to another similar situation. Dewey (1938) makes the strong connection between experience and education, extolling the value of learning from our past experiences.

Eisner (1998) agrees in noting, "One of the most useful of human abilities is the ability to learn from the experience of others" (p. 202). He goes on to say that "all learning involves generalization. Since the test of someone's learning is the person's ability to 
Table 1

Structural Corroboration

\begin{tabular}{lccc}
\hline & \multicolumn{3}{c}{ Data source } \\
\cline { 2 - 4 } & $\begin{array}{c}\text { Interviews } \\
\text { with teachers }\end{array}$ & $\begin{array}{c}\text { Interviews with } \\
\text { literacy coach }\end{array}$ & $\begin{array}{c}\text { Classroom } \\
\text { observations }\end{array}$ \\
\hline $\begin{array}{l}\text { What literacy practices/teaching } \\
\text { strategies are the teachers using } \\
\text { with students? }\end{array}$ & $\mathrm{X}$ & $\mathrm{X}$ & $\mathrm{X}$ \\
$\begin{array}{l}\text { How do teachers feel about the } \\
\text { literacy work they are doing? }\end{array}$ & $\mathrm{X}$ & $\mathrm{X}$ & $\mathrm{X}$ \\
$\begin{array}{l}\text { How do teachers and the literacy } \\
\text { coach perceive their relationships } \\
\text { with each other? }\end{array}$ & & $\mathrm{X}$ & $\mathrm{X}$ \\
\hline
\end{tabular}

display what has been learned in new situations, and since no two situations are identical, generalizations must occur" (p. 202).

It is, of course, my hope that educators will read the descriptions of the coach/teacher interactions in the two classrooms in my study and apply what they see to similar situations, either existing or planned in their own classrooms. Indeed, as Eisner (1997a) said in a lecture to the annual meeting of the American Educational Research Association, "what qualitative research yields is a set of observations or images that facilitate the search and discovery process when examining other situations, including other classrooms and schools" (p. 270). Further, Eisner (1998) ties this thought to generalization when he notes, "The conception of generalization in the context of education research clearly implies that what we learn from an inquiry will be used in other settings or is to be applied to them" (p. 204). 


\section{Ethical Considerations}

Access to the schools in which I conducted my research was not an issue, because I am employed in the school district. In addition, I am frequently in classrooms but do not directly supervise teachers in the district; there was no concern with observations in any classrooms.

I presented, in person and in writing (Appendix E), a full explanation of my research to the Superintendent and the Board of Education of the school district. I also met with and provided written requests (Appendix F) to the principal of each school in which I planned to conduct research.

I met with the full faculties of each high school and described my research proposal prior to administering the SOCQ instrument. Teachers were informed, at that time, of their option to remove themselves from the possible pool of research candidates by not placing their names on the surveys. In this way, teachers selected whether or not they wanted to participate before becoming a candidate and did not have to give a reason

for the decision. I wanted to make sure that, since I have been employed in the district for many years and know many of the teachers well, no teacher felt obligated to assist me with my research project.

Once I had selected possible teachers for further observation and research, I approached the literacy coach and two teachers individually; I fully explained my proposed research and its purpose as well as the timeframe that I was anticipating. My consent form, approved by Andrews University Institutional Review Board (Appendix G), states that

Interviewees understand that they are participating in a research study and that they will be asked to answer questions during several interview settings. They will have 
the opportunity to ask questions and receive satisfactory answers before agreeing to participate in the study. The researcher's observations and the interviewees' comments will be recorded and all information shared will be kept confidential through nondisclosure of the interviewees' names and schools. The interviewees will have the opportunity to review all information before the researcher completes the project.

I followed this procedure with the three teachers involved. Pseudonyms are used for the teachers in the study as well as for the high schools and the school district. However, I know that I work in a small school district and, in writing a dissertation, I will be identified and, indirectly, so will my school district and, perhaps, the buildings and teachers.

Clandinin and Connelly (2000), in writing about narrative inquiry, note that "even when we guarantee anonymity, it is not at all clear that we can do so in any meaningful way" (p. 174). They also say that "we need to consult our consciences about our responsibilities as narrative inquirers in a participatory relationship" (p. 172). Merriam (1998) explains, "While policies, guidelines, and recommendations for dealing with ethical dimensions of qualitative research are available to researchers, actual ethical practice comes down to the individual researcher's own values and ethics. . . Ultimately, the researcher's own conscience informs the decision" (p. 218).

I am professionally and personally (because my work is so much a part of who I am) involved with the coaching initiative and the teachers in my school district. I plan to continue to study, collect data, and nurture this budding and promising mode of professional development. Therefore, I have a professional responsibility to protect the relationships I have with the teachers in my study; this is a responsibility that I have taken very seriously in my research. 


\section{CHAPTER FOUR}

\section{CLASSROOM OBSERVATIONS AND THEME ANALYSIS}

\section{Introduction}

In this chapter I relate my experiences as I observed in the classrooms of $\mathrm{Mr}$.

Stine in WHS and Mrs. James in BHS. My interviews and conversations with the teachers and the literacy coach are interwoven into the classroom stories as appropriate.

Finally, in this chapter, I describe the themes that emerged from the research and tie those themes to current research on coaching and the teaching of reading.

\section{The Classroom of Mr. Stine: The Diary Project}

It is very cold at night, my mommy, daddy and I only get to share one blanket. There are lots of Jewish children here, I wish I could play with them, I still have Marlene, she makes me happy and reminds me of home, I wish I could go home, I miss my Grandma.

It is morning now, many people look upset. I seen many children crying. I asked mommy why there are so many upset people and she said it was because they want to go home. The man with the gun follows them around and yells. I wish he would stop, I am scared. ( $10^{\text {th }}$ grade student diary, 2007)

Soon after our arrival we were moved to a different area. Most men, women, and children were housed in separate quarters. I had the good fortune to stay with my parents in the disabled war veterans' section. Life was especially harsh and strange for children. We slept on the floor or, if lucky, on straw-filled mattresses, packed like sardines on double and triple-deck bunk beds. The rooms were smelly and steamy in summer and freezing in winter. (Auerbacher, 1993, p. 43)

These two quotations- one from a $10^{\text {th }}$-grade girl in Mr. Stine's second period class as she writes in her "Holocaust diary," the other from a book, I Am a Star, written 
by Inge Auerbacher, a Holocaust survivor--sound eerily similar, with both echoing the deep confusion and anguish of a young girl adjusting to life in a concentration camp.

The $10^{\text {th }}$-grade student is in an American History class in a classroom on the first floor of WHS and is writing a daily diary as part of a 3-week classroom project. She has been given a one-page biography of a Holocaust victim-in this case a Holocaust survivor named Inge Auerbacher. The biography came from the National Holocaust Museum's website and is available to teachers for just such projects. The student gleans some basic biographical information from the page and begins the diary with little else. She writes daily entries as though she is Inge and adds historically accurate details based on the lectures that her teacher presents each day in class. But, she also adds her own emotion and feelings to the entries; she has been encouraged to personalize, to try to assume the persona of her "person."

"What we are trying to do is overcome the span of age and the lack of personal connection to help you be able to identify," explains Mrs. Baker, the literacy coach, as she describes the diary project to one class of $10^{\text {th }}$-grade students early on in the Holocaust unit.

After class Mrs. Baker explains that Mr. Stine came to her with a concern about teaching this unit. He has taught the Holocaust unit as part of the history of World War II for 17 previous years, and he deeply believes in the value of students learning about history so that they do not repeat its mistakes. But, Mr. Stine has noticed that, in spite of his personal descriptions of the concentration camp horrors, his iteration of the huge numbers of lives lost, and his own emotional investment in the lessons, each year students seem less impacted by the unit. Mr. Stine is concerned that students are 
becoming insensitive to this horrific event or, even worse, believing the news stories saying that the Holocaust never happened.

"Mr. Stine came to me and asked if I had any idea how to make the Holocaust unit more personal for the students," explains Mrs. Baker.

"I think the one key is engagement through personal connections. If the strategy can help students bridge the gap between what they are reading and what they know, it's a strategy that will work, catch on," explains the coach.

Interviewing Mr. Stine, I ask him about his experiences working with a coach and he, too, refers to this example of the Holocaust unit.

He asks, "How do I get across to students this idea of a 'Holocaust'? It's not even in their frame of reference."

Mr. Stine shares how the Holocaust journals have been a strategy to encourage the students to read and write.

"We need to hook the students on an idea or theme and then find a way to incorporate the reading and writing skills. They love to read what they have written and what their friends have written. It's like reading notes that they pass in class. I never would have thought of that without Sue."

He shares how he now routinely shares thoughts and brainstorms—often by email-with the literacy coach.

"I consider myself to be very organized, but I'm not very creative. We e-mail back and forth. I'm always planning two weeks in advance.".

Then, he says, they work together to make whatever they have planned happen. Mr. Stine describes this process as "so different from a workshop." He says he has been 
to so many 1-day workshops and finds them good but comes away with too much at once.

"This is so much more useful; it's very, very different."

Having recently visited the Holocaust Museum in Washington, DC, with her family, Mrs. Baker knew of the personal identities of victims that are provided to visitors. She tells how she and Mr. Stine logged on to the museum's website and found that they could print off these identities for students to use in the classroom. She then suggested the diary project and offered to come up with the guidelines. She describes how a few days later she and Mr. Stine collaborated to define a timeline for the diary project and to develop a scoring rubric.

"At first, he did not want to give me time in class; the classes are short, only 42 minutes, and he thought he would lose teaching time. But, gradually, I convinced him to give me the last ten minutes of class to work on the diary project."

My first visit to Mr. Stine's two American History II classes is uneventful. I find the classroom fairly ordinary and, although the walls and furniture are old, the classroom is very sensory-stimulating. The walls are completely covered with maps, posters, pictures of historical figures, flags, and vocabulary words. I know that Mr. Stine has a background in the military and his room contains many artifacts of his service in the military and his world travels in that capacity. In addition, there are clocks showing the time at various cities around the world and posters showing several European cities. There is hardly a space in the room that does not display something to occupy the eyes.

Students sit in traditional rows and about three-quarters of the 30 desks are occupied. All are quiet and studiously copying notes from the board. The white board at 
the front of the room is covered with an interesting array of information on the Nuremburg Laws; the notes are written in a variety of colored markers and are arranged very artistically. Yet, in spite of the inviting atmosphere and the obvious work put into the display on the board, the students show little real interest in the lesson. They sit quietly, some slumped over their notebooks and others slouched down in their seats. Their faces passive, they appear to be enduring the 42 minutes that they are required by their schedules to sit in these seats.

Mr. Stine is a good story teller and adds personal experiences to his description of the goings-on of WWII in Europe. Mrs. Baker adds a thought here and there to assist in student understanding of the material.

“De-human-i-za-tion - break it apart. 'De' means less than—think of 'de-crease' in math. Less than human - to make something less than human."

Students are attentive, but the two teachers and I seem to be the only ones enjoying the history lesson. Even though Mr. Stine sprinkles his lesson with questions, he usually ends up answering them himself as the students rarely volunteer answers. Students are well-behaved and the lesson is well-presented; there is just no "spark." Mrs. Baker continually walks around the classroom and occasionally stops to whisper to a student who then sits up straighter or begins to take notes. She sometimes gives a hint or an extension to one of Mr. Stine's questions and even elicits a student response or two. She reinforces the students and Mr. Stine by flashing a smile in response to correct answers.

On my second foray into this classroom, I witness Mrs. Baker explaining the diary project to students. She hands out copies of the instructions for the diary project and 
adds some detail to the written explanation. She also draws the students into the personal aspects of the project.

"Why would we want to remember this 'bad' thing? .. . Soon there will be no one left alive in the world who actually witnessed the Holocaust."

Mr. Stine adds, "How would you feel if something like this happened to your grandparents? If someone killed your grandparents for no reason other than they are Polish or Swedish?"”

Students have their biographical sketches now, and there is some buzzing as they discover that some have Holocaust victims and some have survivors. As student interest begins to grow, both teachers become more animated and excited.

One boy asks, "How do we even know these people existed?"

Mr. Stine launches into an explanation of the meticulous records kept by the German soldiers. Mrs. Baker gives examples from her recent visit to the Holocaust museum. Both teachers use rich language and colorful explanations; the students appear to be getting drawn into the project and its possibilities. Both Mr. Stine and Mrs. Baker have visited the concentration camp sites in Europe, and they collaborate to describe not only what they saw there but how they felt. Students' interest seems to increase as they sit up straighter, leaning forward in their seats, now riveted to the two teachers' descriptions.

Interviewing Mr. Stine, I ask him why he thinks some teaching strategies worked better than others. He states that it is not the strategies that are important but, rather, the teacher's attitude. He believes that students need to see the teacher excited and 
enthusiastic about the material and the work. Further, he notes that one benefit of working with another teacher is that they can feed off of each other's excitement.

"The students seem to respond to our teamwork. They find us more believable when we are reinforcing each other. Does that make sense?"

I can certainly see the "sense" of that statement during this class.

One student asks, "What does 'liberated' mean?"

Another student says, "Free."

Another student asks what name she should assume in the diary, hers or her biographical "person's" name.

Mrs. Baker talks about "walking in another person's shoes" and relates the experience to a current song with which students identify. Students show definite interest in this project and the end of the period seems to come much more quickly than on my previous visit.

After school this day I have a chance meeting with Mrs. Baker and together we process today's observation. She asks if I noticed her speak to a boy in the back of the room during the first-period class. I had not. She says that, as Mr. Stine was lecturing, she noticed a boy writing on a yellow legal pad. She says that, although most students take notes in that class, this student's writing looked like paragraphs rather than notes. She says that he is not the most studious young man, and she assumed that he was writing a note so walked back by his desk. As she looked over his shoulder, she saw that he was starting his diary early, following the instructions on the handout, even though the blank journals had not yet been distributed. 
"Later this afternoon," Mrs. Baker says, "I saw the boy in the library and asked if I could read what he had written. He willingly showed me and what he had written was very good. He showed emotion and involvement with his historical character."

She says, with a smile, that she hopes that this is a sign that students will buy in to the project. Mrs. Baker says she asked the boy if he would be willing to allow her to read his diary entry as an example to the class on her next day there; he readily agreed.

I do not return to Mr. Stine's classroom until 10 days later. At first, it seems that not much has changed. Notes are on the board and students are busily copying them into their notebooks. This time the notes include a beautiful, detailed map of the Blitzkrieg Bypass and the Benelux area of Europe. Vocabulary words are in contrasting colors as they are interspersed in the notes. I notice a girl using colored pencils to accurately recreate the notes in her binder.

Mr. Stine begins to lecture as students finish the note copying. His lecture is again peppered with questions but, on this day, several hands go up to answer each question. Mr. Stine launches into the story of Winston Churchili, his use of the letter "V" in Morse code, its connection to the classical music of the German composer, Beethoven, and how it was used to annoy the Nazis as they attempted to monitor British communication. Students, especially the boys, perk up at this story-I can't imagine that they won't remember this connection forever. So much information is packed into this one explanation - who Churchill was, how Morse code works, the first measure of Beethoven's Fifth Symphony.

The last 10 minutes of this class are devoted to time for Mrs. Baker to connect with students on how their diaries are progressing. She brings a collection of Holocaust- 
era books from the school library and has them displayed on the marker tray of the front whiteboard. In a few short minutes she makes reference to several books and short stories that the students have already or will shortly read in English or Communication classes. One book, We Are Witnesses, is a compilation of the diaries of five teens who died in the Holocaust. Later, I have a chance to read two of the diaries-powerful stuff?

Students are given time to get in groups of three and read excerpts from each other's diaries. They seem excited to do this and not at all nervous about having someone else read what they have written. Both Mr. Stine and Mrs. Baker walk around the room as students engage in this activity. This time goes quickly and both teachers encourage the students to keep writing as the diaries will soon be due.

In a formal interview with Mrs. Baker, I ask her thoughts about effective teaching strategies.

She explains, "I really feel strongly that team teaching is effective. Why? Because I feel that differing perspectives and examples that two teachers can offer to a group of students is beneficial. Also, varying personalities of teachers can help to motivate students or encourage them to engage in the lesson."

This "tag-team" approach of Mr. Stine and Mrs. Baker seems almost choreographed and works well to engage students in lesson content.

I ask how this almost symbiotic relationship came about. Mrs. Baker's answer says a lot about the coaching process.

"I guess a good word would be 'slowly.' The relationships are not immediate, but evolve based on common trust and non-evaluative, non-judgmental talk. . . The whole process is incremental beginning with simple, small, short lessons that evolve into more 
elaborate, detailed plans. The most successful relationships have been those that have gone from elaborate coaching interactions to increasing teacher ownership."

"When Mr. Stine said to me, 'When $I$ do this next year ...' It didn't really matter what he said after that because I knew that he was going to adopt this lesson/strategy as his own and use it in future years. Now I can just go on to something else and not have to worry about that. Like when the war poetry, double-entry journals that we worked on last year simply appeared this year without any request for my help. All I had to do was walk by the display and smile."

Soon after this observation, I again have a chance meeting with Mrs. Baker. She is excited to share some news with me.

"We are taking a field trip to the Holocaust Museum," she says with a big smile.

She explains that she and Mr. Stine talked about what a great culminating activity that trip would be but didn't think it was possible. On a whim, she called the museum and they had one group time open on June $11^{\text {th }}$, the Tuesday of the last week of school. So, Mrs. Baker explains, she quickly reserved the time and went to the building principal for his help. Even though June $11^{\text {th }}$ is during finals week, the building principal is convinced of the value of the Holocaust project and says that, if Mrs. Baker can find the money for the trip, he will re-arrange the students' finals schedule. With one more hurdle overcome, Mrs. Baker says she went to a local foundation for the $\$ 1,000+$ needed for a coach to Washington, DC. Her excitement today is a result of just receiving a check from the foundation.

"Do you want to chaperone?" she asks.

Excited, too, I agree; I wouldn't miss it! 
A few days later, as I enter the classroom of Mr. Stine for what turns out to be my final day of observations, I find the room a-buzz with activity and excitement. Students are writing in their diaries while Mr. Stine and Mrs. Baker are moving throughout the room, reading what students are writing. Mrs. Baker explains to me that the journals are due on Monday (today is Friday) and they want to make sure that everyone is "on track." So, they are taking the last part of the period to concentrate on the diary project.

At Mrs. Baker's suggestion, two boys close to me allow me to read their journals. The first boy's "person" is a survivor; I tell him that I am excited about that and he agrees. We talk briefly about what his character might have eaten as he was hiding from the Nazis for seven years-I don't think either of us comprehends the life of this Jewish boy. The writer of the second diary I read has written about a meal being eaten by his character's family and we talk about why they wouldn't be eating ham in a Jewish family. The class ends while we are talking.

The two diaries I read are very good-full of detail and emotion-and the boys are fun to talk with. I think they have done a great job of mixing their classroom-gained knowledge with their own fictional interpretations of their characters, and their writing is very entertaining.

The second class progresses in the manner that I now expect in Mr. Stine's classroom. Detailed notes are copied from the board-this time on the Battle of Britainand the lecture includes the playing of the British National Anthem. Mrs. Baker gives me a copy of the next writing project that she and Mr. Stine are collaborating on, this time a comparison of parts of Churchill's speeches and several famous poems of the era. Students are attentive and readily answer questions as they copy the notes that include a 
map, vocabulary words, and several quotes from Winston Churchill, obviously a favorite of Mr. Stine.

The second half of the period is again used to work on and review student diaries. Students around me are sharing their diaries with each other, and this time I am not offered diaries to read, but I enjoy "eavesdropping" as they describe what happens to their characters. Students are animated, and I overhear both teachers offer encouragement and compliments to students as they move from desk to desk, student to student. It seems that the Holocaust diary project is successful; it has engaged students and, seemingly, invigorated this traditional classroom.

I hear Mr. Stine speaking to a female student two seats in front of me. The excitement in his raised voice catches my attention.

"Mrs. Baker, come over here. Amy, tell Mrs. Baker what you told me."

Amy says, "Well, I am e-mailing back and forth to my "person."

Mrs. Baker's face shows first confusion, then surprise, then a smile. I, too, struggle to understand and listen intently.

"She's alive-my sheet says that she lived so I 'Googled' her name. Her name is Inge Auerbacher. She's alive and lives in New York City. I e-mailed her and she emailed back. We have been talking, but I want to ask her about the Holocaust and what it was like. I don't know if I should. I'm afraid it will upset her."

Amy talks matter-of-factly, as if this is just common, everyday procedure.

Mr. Stine says, "Amy, do you know how special this is? What percentage of students would take a project this far? Do you know how far over and above you have gone?" 
The excitement and emotion in his voice say volumes about the success of the Holocaust diary project. Mr. Stine continues to talk to Amy about how she can best broach the subject of the Holocaust with Inge. Other students listen intently as the bell rings and class ends.

After class, as another class moves into their seats, Mrs. Baker, Mr. Stine, and I share our amazement at what we have just witnessed. Amy is not an academically strong student; she is not the student that a teacher would expect to excel, to do extra-up to this point in my observations, I have not even noticed her. Yet, she has just made an announcement that has literally stopped all three of us in our tracks. We know we have witnessed something special but aren't quite sure of the next move. Wow! Here is one student of the Holocaust who will never be the same.

Mr. Stine describes his work with Mrs. Baker in several ways. Each captures a different theme of the coaching process.

Describing his desire to continue to improve as an educator, Mr. Stine says, "I feel that I have to be competent-period. My military background has taught me that you have to be able to do your job. It's not completely natural to ask for help. But, I don't let my pride get in the way of being a better teacher."

Later, he describes how his relationship with the literacy coach has evolved from the formality and sometimes uncomfortable first few months. "I don't want to speak for Sue but I believe that we have a good thing going. Now I don't bother her when I can do some reading strategy or other on my own. But, I know I can e-mail her or stop her in the hall if I have a question. Lots of times I just want to run something by her." 
Mr. Stine says that his dependence on Mrs. Baker varies according to the reading or writing strategies that he is using. "I look at her as a resource, someone to bounce ideas off. .. . For instance, do I need her to come back and help me with the 5-paragraph essay? No, my training wheels are off with that one."

"I don't think I was doing a bad job before-but now I am doing more enrichment," explains Mr. Stine. He adds, "Working with a reading coach is my first real experience with team teaching in my career. . . You can actually do some of that; this is the first time I have seen that. In some ways, I am sorry that I missed that for 18 years."

In further analyzing how his classroom instruction has changed as a result of the teaching relationship with the literacy coach, Mr. Stine says, "It is very hard to explain what is happening. I don't feel like I am teaching any differently or any different material. But I am integrating language arts into history and it is sort of seamless."

Following is the "found poem" that I wrote in an attempt to capture the essence of the Holocaust project and its impact in Mr. Stine's classroom.

The Holocaust Project

A classroom

In any school

Students sitting in rows

Ordinary students

Dressed in browns and blacks

Looking bored

Taking notes

Faces blank

A room filled with stuff

History stuff

Words on the walls

Words on the board

Words written with colored markers

Neatly organized

Students copying 
Looking bored

A teacher up front

Telling stories

Stories about a war

Horrors of war

A Holocaust

Stories of people

And how they died

A teacher

Knowledgeable

Well-traveled

Sharing his knowledge

Students polite

Participating when pushed

Looking bored

A student project

Another teacher

Talking about writing

A diary

A Holocaust victim

Or

A survivor

How did he live?

How did she die?

A diary

Telling the story

From the student's eyes

Assume the identity

Write

Write some more

Write and share

A classroom

A special classroom

In a special school

With special teachers

Students excited

Writing and sharing

Empathizing

Understanding

A Holocaust

Life was horrific 
For so many

Life was over

One student

Taking a step

A step beyond

"She's alive."

"I talked to her."

My person

I found her

Can we meet her?

Can we bring her here?

A survivor

\section{The Classroom of Mrs. James: English or Reading?}

"English teachers may teach developmental reading" (p. 1) and "Developmental

Reading is reading beginning at each student's actual grade level for the purpose of

furthering developmental functional reading skills" (p. 1). Both of these statements are

from the PDE Certification-Specific Program Guidelines (Pennsylvania Department of

Education, 2004a), describing the work that may be undertaken by teachers with the

secondary English certification in the state of Pennsylvania.

Mrs. James, English teacher at BHS, does not have a reading certification, although she is currently working on one. But, she is passionate about reading-both her own and that of her students.

"I was always an avid reader and that led me to a major in English education. But, now I realize that my ability to read easily made it harder for me to work with struggling readers," says Mrs. James during our formal interview.

Although I am observing Mrs. James' seventh-grade English class, I see many examples of Mrs. James working with reading. Although I originally selected Mrs. James 
as a content-area teacher who was working with the literacy coach, the lines between English instruction and reading instruction quickly blur for me.

In my first visit to Mrs. James's classroom, I am overwhelmed with the room itself. First, the room is very large-so large, in fact, that there is room for 26 student desks, a teacher desk and a small computer table at the front of the room, and two large work tables at the back of the room. But the amazing part is the student work; there are posters, mobiles, and other student art work everywhere: on the shelves that line two walls, on the tops of the shelves, on the few remaining bare walls, on the tops of the filing cabinets, and on the window sills. I count 25 mobiles hanging from the ceiling, many of them vocabulary-based. Most of the posters and many of the other pieces of student work are written materials or materials in some way word-rich. Words are everywhere in this room, and the displays show a great respect for the students and their efforts as well as an appreciation for the use of language.

The classes I observe over a period of several weeks focus mainly on vocabulary and parts of speech. But, gone are the grammar books that I remember so well. Although there is evidence of some drill and practice, most of the student efforts go much deeper.

Mrs. James does very little lecture; in fact, the majority of the 84-minute classes feature the students. As the day begins and students watch a television that displays student-presented announcements, news, and weather, Mrs. James circulates. At first, I think she is just checking to see that homework is complete. Once she begins calling on students, I realize that she has also been looking for correct sentences that can be successfully transferred to the whiteboard in the front of the room. As she sees good examples, she sends students to the board. 
But, students left in their seats do not have the opportunity to vegetate either. Mrs. James engages every student in some conversation about the topic which today is adverbs. Students actively react to the work on the board.

"If you think that one is correct, shake your head from left to right," says the teacher. "How would you change it?"

Some details are changed for clarity — by the students. Students are engaged in a deep discussion of individual words and their usage. Mrs. James speaks quickly and confidently; the pace of the class is quick, just right for most lively seventh-graders.

"I have always talked to the kids about how and what they are thinking; that is a strength for me. I develop a trusting relationship with them; we can talk. I just ask the kids, and they tell me if they don't get it."

Mrs. James does talk to the kids and they talk back. She asks questions and uses wait time effectively. In every case, students answer correctly and, many times, Mrs. James follows up with a "Why?" or "Why do you think that?" question, further enhancing the learning.

Her questions and language are intriguing to me and, obviously, to her students. "Jess, tell me what I just did? Did you hear me or did the heater eat up my voice?" "How many of you, when you study for a test, close your eyes and visualize the page it is written on in your notes?"

Later, Mrs. James explains to me, "I think the key is to get the kids thinking; that's the whole metacognitive thing." 
By 20 minutes into the class, I am aware that Mrs. James has spoken at least once to every single student and every student has responded correctly at least once. If I didn't know better, I would think this was planned just for me.

As the class leaves the study of adverbs, with a reminder that they will return tomorrow, students turn to their literature books and a story that has obviously also been homework. Quickly, Mrs. James brings up an "inference chart" on the board and there begins a lengthy discussion of clues, background knowledge, and inferences. The students give examples from the story and Mrs. James gives examples from her own reading outside of the classroom. She talks to the students about the "little voice in my head" that helps her to build connections between what she knows and what she is learning.

In our discussion later, I refer to these reading strategies and ask about Mrs. James's background in teaching reading.

"As far as instruction on how to read or how to teach others to read, there was none of that in my undergraduate work. Classes I have taken on cooperative learning and Reading Apprenticeship (RA) have helped immensely. Of course, RA was not new to me; Sue had given us a preview. I thought, 'Doesn't everybody have a voice in their head?' I did and I just didn't realize that everyone doesn't."

This 84-minute class just flies by and I really feel like the students are engaged and that learning is happening. But, the energy this morning is nothing compared to what I find the next time I visit Mrs. James's seventh-grade English classroom!

Two weeks later, I am back, this time to observe on a day that Mrs. James and Mrs. Baker are team-teaching a lesson, this one on the week's vocabulary words followed 
by conjunctions. Instantly, I notice an even higher level of activity and energy; the room seems to be humming as the students enter.

The two teachers are deep in animated conversation as the students meander into the room and find their seats. I overhear bits and pieces: "vocabulary," "my $10^{\text {th }}$-graders," "They loved it!" I guess that Mrs. James is describing to Mrs. Baker some successful lesson that she recently taught.

Soon, the announcements begin on the television and two seniors come in to talk to Mrs. James. Mrs. Baker quickly leaves the front of the room and begins to make the rounds of students' desks and homework that is out and ready. In a few minutes, Mrs. James begins a classroom discussion of the vocabulary word sentences, using the same process I witnessed in my last visit.

Mrs. Baker is obviously comfortable in this room. She knows the students all by name and the discussion of vocabulary words flows easily into what parts of speech they occupy as they are used in the student sentences. She interjects at times and calls on students in tandem with Mrs. James. The word I use to describe their teaching is "seamless."

Mrs. James continues to lead the interaction with questions such as "How is it used in the sentence?" and "If I was diagramming it, what would I put on the line?" She continually reminds students to look for context clues.

Shortly, it is on to grammar and Mrs. Baker takes over at the front of the room. As she introduces the topic of conjunctions, Mrs. James moves among the student desks. I hear her say to a student near me, "You need to write this down." 
Mrs. Baker asks for prior knowledge and several students give answers from their experiences with words and sentences.

Quickly, Mrs. Baker moves on to an activity that gets seven students up and in front of the room. The students work together to create a sentence and, after figuring out the word sequence, end up holding hands in a row. The activity "connects" them and, simultaneously, gives an acronym for remembering the seven connecting conjunctions.

In an interview with Mrs. Baker, she talks about helping students to make connections in their learning.

"They have a wealth of information they already know, that is under-utilized. Simply illustrating the methods or strategies needed to make connections is all that is needed. The idea of 'cognitive Velcro'-they have stuff in their brains; we just have to create the connections, the Velcro for new stuff to stick to."

Back in seventh-grade English class, Mrs. James chimes in with, "Close your notebooks. Who can say the seven connecting conjunctions?"

One student raises her hand and says them correctly.

Mrs. Baker exclaims, "Give her a hand!" and they all start clapping.

The lesson continues in this high-energy, high-activity, and high studentengagement mode. I find myself watching instead of taking notes - the action is mesmerizing. These two teachers work so well together. They are the definition of teamteaching.

Mrs. James tells me how much she enjoys these cooperative lessons.

"I just love the coaching. It has flowed into team-teaching, true team-teaching. We just work so well together. One pops in and the other pops out." 
"Popping in and out" is a good description of the activity I witness. I wonder how the students feel about having two such energetic teachers.

Mrs. James answers my question this way, "Students really don't know what to make of it, especially the junior high students. I didn't really discuss it with the students; we just did it. We tag team. One of us is teaching while the other one 'works the room.' Or, you know it is hard to write on the board while you teach, so Sue will just come up and start writing on the board while I talk or I will do that when she is teaching. Or she will be in the back and will say, 'Mrs. James, hold on, we have a question over here.' I might miss that student's question if I am by myself.

"The team-teaching works so well on so many different levels. One of us can just be observing students. If we see someone having trouble, we can quietly give a hint or show him or her where we are. If a student has been absent, Sue will just sit next to him and quietly help him get caught up. It really relieves some of the anxiety of the younger students who are still nervous about being here."

As the class moves into the last 20 minutes, Mrs. Baker says, "Now we're going to kick it up a notch."

I am thinking, "How can these two get any more energetic?"

But, they do have a surefire way to keep the students engaged right up to the bell.

Mrs. Baker continues in her best melodramatic voice, "Mrs. James is going to be my guinea pig. I am going to give her a sentence and she is going to diagram it on the board. This has not been rehearsed!"

Mrs. Baker dictates as Mrs. James writes, "The hyperactive English teacher and the abnormal literacy coach came and conquered." 
The students do some giggling and squirming in their seats but are riveted to the board as Mrs. James proceeds.

After class I comment on this strategy and Mrs. James tells me that she is weak in grammar and that she has learned a great deal from Mrs. Baker in this area. "I have been right up front with the kids about this. So, the students know that Mrs. Baker is the 'grammar queen' and they know that I am learning along with them some of the time, especially on the hard stuff."

Mrs. James does a wonderful job of showing her own metacognitive processes as she explains what she is thinking as she diagrams. Students encourage and even cheer when she gets something correct.

Mrs. Baker says, "It's very logical, almost like a math problem where you are plugging in the numbers to a formula."

Next comes an extension activity with the same sentence and Mrs. Baker asks students to add adverbs.

Mrs. James says, "Remember, who do the adverbs hang out with? They only hang out with three other parts of speech."

Students come up with the correct answers and together the now complicated sentence is correctly diagrammed on the whiteboard.

"Okay, now I have another sentence and guess what? Mrs. James is not going to diagram it. You are!"

As the students work, both teachers move from student to student, encouraging them to talk through what they are thinking and doing.

"This one's tricky." 
"Told you we were going to kick it up a notch."

"It's okay, we will tweak it."

"'She's a trickster, that Mrs. Baker."

The seventh-graders completely buy in to the light banter that flows so easily between the two teachers. They are totally engaged in the competitive, yet accepting, atmosphere of the classroom. Once the teachers are sure the students have the concept down, students are allowed to write diagrammed sentences on the whiteboard.

"Okay," says Mrs. Baker. "As soon as Jess is done up here, we are going to see if Mrs. James can diagram a sentence with a correlative conjunction. Dah-da-da-dah!"

Students laugh as Mrs. James "hams" it up by giving Mrs. Baker a dirty look. The class continues with this topic. Students critique Mrs. Baker's work and then go on to complete their own examples, again with lots of attention and feedback from the two teachers. The 84 minutes end with just as much energy and enthusiasm as at the beginning - and a challenge. Mrs. Baker tells the students that, when she returns to their classroom in 2 days, they can try to stump her with a sentence to diagram.

How do these teachers maintain this seeming coordination of activities when one is here only half the time? I pose this question to Mrs. James during the formal interview.

"We both depend on e-mail a lot. Plus, Sue has a good sense of what I know and don't know about reading. We have worked together a lot and developed a good relationship. I can read her, too. We just complement each other."

Mrs. Baker, too, refers to the time taken during her first year as coach to build relationships with teachers. 
"The relationships are not immediate, but evolve based on common trust and nonevaluative, non-judgmental talk."

Mrs. James agrees, "Sue's personality and the way she is - it just makes it so easy. You don't feel like you are being watched or criticized. . . It just flows - we just feed off one another."

On another visit to Mrs. James's classroom, I see her review the conjunctions and then move on to a poetry lesson. The poem is The Jabberwocky, and students are learning about limericks. Again, even though this is a single-teacher day, the enthusiasm is high and students are engaged in the lesson. After discussing thoroughly the characteristics of a limerick, students are asked to choose their own personal "golden words" from the poem.

When asked to talk about the reading strategies she feels comfortable using in her classes, Mrs. James recites a list that begins with "golden line or word."

"Working with Sue and the activities in RA has given me a comfort level with many of these strategies. I can just 'do' them now. I can integrate them into all my classes. I use them all day long every day," she explains.

Students, too, seem comfortable with this reading comprehension strategy as they take turns with their "golden words." Students demonstrate that they know how to use this reading strategy to increase their comprehension of even a nonsensical limerick.

On still another classroom visit, I again see Mrs. James and Mrs. Baker in the room together. They work together to check homework and I hear Mrs. James speaking to Thomas about homework not being complete.

"This is the second time this week," she says and moves on quickly. 
As she begins going over the vocabulary words from the front of the room, Mrs. Baker quietly pulls a chair right next to Thomas. While Mrs. James moves from student to student, giving each a chance to respond, Mrs. Baker quietly speaks to Thomas as he writes. Soon he has a chance to redeem himself as his hand goes up to answer a question. He answers correctly, and Mrs. Baker gives him a pat on the back.

Soon Mrs. James announces, "Take out your parts of speech and a writing utensil."

With that, the two teachers quickly trade places with Mrs. Baker going to the front of the room and Mrs. James taking the seat beside Thomas. Mrs. Baker tells the class they will quickly review the parts of speech before vacating "grammar town."

"But, we may re-visit," she says with a smile.

After a quick review, the students move on to the assessment on parts of speechnot a typical test but something called a "parts of speech triangle." Both teachers pass out the papers and Mrs. Baker shows and explains a model of what a correctly completed triangle looks like.

Students set to work with both teachers moving from desk to desk, giving feedback and encouragement.

"Okay, we have a lot of good nouns here."

"Now, you can personify the doughnut."

"Good job, nice job."

The class proceeds much like the previous days that I visited. The work is interesting and students are engaged. With two teachers in the room, no one is allowed to flounder although, truthfully, everyone seems to "get" it. They move from the triangle 
activity to beginning a four-cell cartoon using interjections. Again, a model is presented and the students jump right in to the activity which is to be completed for homework.

I ask about the many activities and strategies that seem to weave so easily through the class time.

"They get all the kids involved," says Mrs. James. "That's so important because the education system puts kids in slots in the classroom. The 'quiet' ones never share. Now I can walk around the room and see what kids have written and have a student who never raises his hand give an answer that I know is correct."

Simultaneous to these classroom visits, I am also working with Mrs. James, Mrs. Baker, and several other CSSD English teachers on the development of reading courses for seventh- and eighth-grade students. After several meetings spent examining research on adolescent reading, the committee decides to develop curriculum for the reading courses based on the Reading Next (Biancarosa \& Snow, 2006) report findings and the Reading Apprenticeship framework.

Notes from a committee meeting held near the close of the 2006-07 school year say, "The committee decided that the courses will use the Reading Apprenticeship model as the foundation and instruction will include reading strategy instruction, practice in reading with strategies using literature and content texts, verbal and vocabulary review, literature circles, DI (differentiated instruction) Boards, focused free-writing and journaling, and independent reading using the Reading Counts program."

Many of these activities are already being used in Mrs. James's English classes. So, I am not surprised when, at a junior-high reading curriculum meeting early in the 
2007-08 school year, Mrs. James and Mrs. Baker are leading the charge with the reading courses in CSSD.

One last visit, this time to Mrs. James's eighth-grade reading class (last year's seventh-grade English students), yields yet more confirmation of an increasingly strong literacy program. Again, Mrs. James and Mrs. Baker are teaming and, this time, the students are in the computer lab. They are using a program called Think.com to conduct on-line literature circles with students in a seventh-grade reading class in WHS and undergraduate students in a reading methods class in a nearby university. The reading teacher at WHS has set up the working relationship with the professor teaching the university course. Mrs. Baker brought the information from WHS to Mrs. James and helped her set up the program at BHS.

Students in all three venues have, in groups, read the same books and use the discussion board built into this free program to discuss what they have read. The budding teachers in the university methods class take the lead by integrating "helps". such as explanations of difficult words into their discussions.

Today students are given the directions to read the postings that are up in their individual circles and to respond with at least two postings.

Mrs. James, ever the English teacher and the cheerleader, says, "Use good grammar and punctuation, your best writing skills. BHS students will set the standard."

Later she tells me about this experience using technology for the literature circles. "I wasn't going to do that this year; it seemed like too much. Sue encouraged me to diverge from the other class and try it. She has taken the lead even though she is 
learning it with us. She just encouraged and helped to pull all the pieces together. It takes two of us in the lab to keep the kids on track. But we are both learning together."

Students are engaged and appear to enjoy using the technology. As Mrs. James says, both teachers are kept busy monitoring student work and answering questions, but it is a cheerful and productive kind of busy. Both continue to smile as they work together on yet another new literacy endeavor.

\author{
English or Reading? \\ Vocabulary words \\ Parts of speech \\ Grammar \\ Short stories \\ Novels \\ Poetry
}

Golden line

Talk to the text

Double-entry journals

Context clues

Metacognitive logs

3-2-1

Students writing

Reading

Asking questions

Writing some more

Teachers

One or sometimes two

Desk to desk

Student to student

Time for everyone

Each child writes

Teachers read

Each child speaks

Questions

Always questions

Why do you think?

How does that work? 
What does that mean?

Show me

Teachers talking

Planning

Activity - and activities

Interesting activities

Students engaged

Where do you come up with them?

We talk.

We plan.

Reading courses

Just for reading

Strategies

To understand

All kinds of texts

Vocabulary words

Literature circles

How do I read?

How do I make sense?

Metacognition

Team-teaching

Plan on Fridays

Teach every day

I teach English

I teach reading

I teach students

To understand

What they read

What they need to know

To find the answers

To be successful

To survive

\section{Emergent Themes From Two Classrooms}

As I collected information in the classrooms of two content-area teachers in

Countryside School District, I was also looking for concrete examples of how this coaching work happens and how the relationships between the teachers and the coach develop and continue. Four themes emerged quite clearly from the data I collected. All 
certainly relate to the literature but, clearly, show a wider variety of interaction than I had originally expected. The themes appeared throughout both classroom observations and across my conversations with the teachers and the coach. The themes speak to both the literacy strategies that the teachers are using, their perceptions of their work, and their relationships with the coach.

The first thing that I noticed in each of the classrooms where I observed was the abundance of a variety of sensory-language material. This emphasis on language and literacy was a strong component of each classroom, was clearly noted in teacher interviews, and constituted a strong theme. Another prominent theme I saw was that of the coach as a role model. The literacy coach is meant to be the expert in the integration of literacy activities into contert-area instruction; therefore, the data supporting this theme are critical. Repeatedly, in interviews and observations, an additional theme of the classroom teacher and the literacy coach working as a team was revealed. The teaming aspect was a bonus and strongly supported the transfer of literacy instruction to the students. An additional and fourth theme was that of the coach as a validator of the classroom teacher and his or her instructional methods. This was a surprise to me, as the two teachers selected for the study were veteran teachers.

Finally, interviews and conversations with the teachers led me to explore the idea of what makes the coaching model work, a knowledgeable coach or a coach with an appealing personality? This was a question addressed in the literature but not one that I had originally intended to pursue. 


\section{Language and Literacy Theme}

My first visits to the two content-area classrooms began with photographing the empty classrooms and writing descriptions of the environments. In both classrooms, I was impressed with the variety and abundance of words and language displayed. In Mr. Stine's classroom, I noted that the room was very sensory-stimulating with the walls completely covered with maps, posters, and flags from various countries. In Mrs. James's room, I noted all kinds of mobiles hanging from the ceiling, many of them being vocabulary-based. I followed by observing that the room was language-rich with words everywhere.

Later in my observations and interviews, I continued to note this pattern of the wide use of language and vocabulary. Both Mr. Stine and Mrs. James dominated their respective classrooms both with language and with the use of content-related vocabulary.

Mr. Stine used much more lecture in his instruction, but his lectures had a definite story-like quality and included a plethora of detail and description. He wrote wonderful notes on the whiteboard, beautifully printed, and filled with exotic names and colorful comments. In addition, his lectures were peppered with personal reflections from his military career and his time spent in Europe. When asked about the reading strategies he uses, Mr. Stine had difficulty in recalling the names of the strategies but enthusiastically described his love of the English language and the study of words. He told how he enjoys discovering and sharing word origins with his students. In addition, he shared how acronyms and mnemonics have assisted him in learning and remembering; in an effort to promote his students' comprehension, he said that he shares those strategies with them. 
Mrs. Baker was able to relate and give detailed descriptions of the reading strategies she has modeled and assisted with in both Mr. Stine's and Mrs. James's classrooms. Many of them, like think-alouds and effective questioning, rely heavily on oral language to bring cognitive processes to the surface.

Mrs. James also filled her classroom with oral language, but her talk was extremely student-interactive. In my first visit I noted that, 20 minutes into the class, every student had participated in some oral response and many had answered several questions. The students were comfortable to respond due to Mrs. James's strategy of moving throughout the room to view written homework before prompting students with correct written responses. When asked about her use of reading strategies, Mrs. James was fluent in her listing of specific strategies, citing many and telling how and when she used each. She readily described her own use of metacognitive language and how it has helped her to be an efficient and understanding reader. Mrs. James noted that her discovery that not all readers automatically use metacognition was a turning point in helping her understand the value of using the reading strategies suggested by Mrs. Baker.

Table 2 depicts how language and literacy activities were evident throughout the two classrooms and in interviews with the teachers.

An extensive vocabulary and the ability to know, understand, and use a large number and variety of words are critical to reading and listening comprehension and to school success, especially for middle and secondary students. It is every teacher's responsibility to develop students' vocabulary knowledge of not only words specific to each discipline but also those more general words used across disciplines. (Rhoder \& Huerster, 2002, p. 730)

Limited vocabulary and/or background knowledge is one reason for poor student comprehension of challenging secondary-level text (Allen, 2000). Classroom teachers are the content experts; they hold the language that is essential for comprehending and 
Table 2

Value of Language and Literacy Activities

Data collected from: $\quad$ Examples
Mr. Stine's classroom Classroom is very sensory-stimulating, walls completely covered w/ maps, posters, flags, etc.
Tells stories, lots of detail.
Nicely printed notes with vocabulary words in contrasting colors; explanations are peppered with personal reflections.
Interview with Mr. Stine
"I do lots of little things and don't really worry about the names." Uses VENN diagrams, lots of etymology- particular love of his-enjoys discovering and sharing the origins of words. Military background lends to the use of acronyms and mnemonics as memory devices.

Interview with Mrs. Baker

"Think aloud, talking to the text, double entry journals, reciprocal teaching, question and answer relationships."

Mrs. James's classroom

All kinds of mobiles hang from the ceiling, easily 25 of them. Many of them are vocabulary-based.

The room is so language-rich. Words are everywhere.

Interview with Mrs. James

"Doesn't everybody have a voice in their head?" I did and I just didn't realize that everyone doesn't.

"Well, I use a lot of this stuff everywhere, Grades 7 through 12: the 'golden line or phrase,' give one/get one, talk to the text, double entry journals-I've been doing these forever, coding text, reading or metacognitive logs, anticipatory logs, graphic organizers-but not consistently, 3-2-1 - all the time, jig-saw - but I modify it lots of times, QAR." 
learning the content. Santa (2006) notes that teachers are on "stage" and "they show, tell, demonstrate, and explain not only the content but also the process of active reading and learning" (p. 489).

Vocabulary is not the only piece of the reading and comprehension puzzle, but a language- and word-rich environment are recognized as critical for reading. The Reading Apprenticeship framework (Schoenbach et al., 1999) lists knowledge-building as one of the four critical dimensions of the reading classroom; knowledge-building includes the discipline-specific vocabulary. Finally, in its annual list of "hot" topics in adolescent literature for the year 2006, the Journal of Adolescent \& Adult Literacy lists vocabulary as "very hot" and cites the close relationship between comprehension and vocabulary (Cassidy, Garrett, \& Barrera, 2006, pp. 35-36).

Clearly, part of the work of the literacy coach is to infuse the classrooms in which she works with language-rich strategies. However, both Mr. Stine and Mrs. James indicated deep knowledge of and interest in the vocabulary and word usage of their disciplines prior to their work with Mrs. Baker. It is certainly very possible that their value of language inclined them to be more open to the work of the literacy coach. In any case, the value and richness of language was evident in these classrooms and supported the literacy initiative.

\section{Coach as a Model}

In both Mr. Stine's and Mrs. James's classrooms I observed the literacy coach as she modeled specific instructional strategies and content. In the social studies classroom of Mr. Stine, the modeling involved the diary-writing project for the Holocaust unit and, later, the book talk involving the nonfiction and historical fiction books from the 
school library collection. In Mrs. James's English and reading classroom, Mrs. Baker became the lead teacher often as she modeled grammar lessons, diagramming sentences, grammar projects, and the use of the digital literature-circle software. Mrs. Baker did not model an entire lesson, per se, but rather assumed the modeling role whenever she owned the expertise of the particular topic. Prior planning and discussion had allowed for the time devoted to the instruction and strategies that the coach brings to the classrooms.

Mr. Stine shared with me that, with the help of the coach, he had found ways to encourage students to read and write; he was able to incorporate more writing assignments. He gave the example of the Holocaust journals, the five-paragraph essays, and compare-and-contrast essays. He said that Mrs. Baker took the lead by helping him to develop the assignments and the scoring rubrics. Mrs. Baker demonstrated the strong connection between reading and writing, and, working together, the two teachers made word study and other strategies part of particular lessons.

Mrs. Baker supported Mr. Stine's analysis of the various cooperative projects. She explained that the most successful relationships have been those that have gone from elaborate coaching interactions to increasing teacher ownership. "When Mr. Stine said to me, 'When $I$ do this next year...' it didn't really matter what he said after that because I knew that he was going to adopt this lesson/strategy as his own and use it in future years. Now I can just go on to something else and not have to worry about that. Like when the war poetry, double-entry journals that we worked on last year simply appeared this year without any request for my help. All I had to do was walk by the display and smile."

Mrs. James shared that, as an avid reader and language arts teacher, she had used many reading activities in her classes. But, while observing the coach, she learned 
additional strategies and also gained a deeper understanding of how students grow in comprehension from their experiences with metacognition. Additionally, she reflected that grammar was a weak spot in her secondary and postsecondary education and that she had never learned to diagram sentences. "I first thought that was a waste of time, but Mrs. Baker made a game of it and I realized that the students learned by making visuals of sentence structure, especially those with the math brains. And, my knowledge of grammar has been strengthened."

Later in our conversation Mrs. James described how she, Mrs. Baker, and a third language arts teacher meet each Friday afternoon to plan for the next week's classes. "We all add our thoughts but she [Mrs. Baker] has the detail on the metacognitive conversation piece. If I had not had her, I would have been moving much more quickly in the reading classes. We would have started literacy circles two or three weeks ago. Sue knows how this is supposed to go. She pushes for us to work with the kids on the metacognition."

Mrs. Baker described the planning sessions also and said the value is more in the reflection than in the planning. Noting how the three teachers discussed what worked and what didn't, she added, "My personal modeling of reflective decision-making has prompted other teachers to act more thoughtfully about lesson successes or failures."

Table 3 shows evidence of the coach working as a model for the secondary teachers.

In its 2004 delineation of the position of a reading coach, the International Reading Association states that it is "essential" that coaches be "excellent classroom teachers themselves" (p. 3) and that they have the "experience or preparation that enables 
Table 3

Coach as a Model

Data collected from: Coach as a model

Mr. Stine's classroom $\quad$ Mrs. B takes over-begins to explain writing project. Mrs. Baker is "on" again with the display of library books. She talked about various "genre" such as "nonfiction" and "historical fiction."

Interview with Mr. Stine

"Sue suggested we do a 5-paragraph essay on the topicI was skeptical but she said, "Would you like me to come in and help?"'

Interview with Mrs. Baker

"My personal modeling of reflective decision-making has prompted other teachers to act more thoughtfully about lesson successes or failures."

"The most successful relationships have been those that have gone from elaborate coaching interactions to increasing teacher ownership."

Mrs. James's classroom

Grammar-Mrs. B takes over at the front of the room. Mrs. B has taken the lead on designing this activity. Mrs. J tells me that she was not feeling competent to integrate the Think.com part of the literature circles and was going to wait until next year. Mrs. B offered to set this part up and work through it with her.

Interview with Mrs. James

". . . others I have learned through Sue ... now I understand how many of the reading strategies help students comprehend what they read." "... she has the detail on the metacognitive conversation piece. If I had not had her, I would have been moving much more quickly in the reading classes." 
them to master the complexities of observing and modeling in the classrooms and providing feedback to teachers" (p. 4). In 1980, Joyce and Showers's analysis of over 200 studies of teacher-training activities demonstrated that new instructional skills "stick" if teachers are "provided opportunities for any combination of modeling, practice, or feedback" (p. 381). Descriptions of coaches from a variety of additional sources include modeling as a critical role of the position (Blachowicz, Obrochta, \& Fogelberg, 2005; Moffett et al., 1987; Sturtevant, 2002). Poglinco and Bach (2004) give strong support to the modeling piece of coaching with this statement: "Of all the techniques coaches employ, modeling instruction in individual classrooms is most likely to result in modification in instructional practices and adherence to the instructional delivery formats" (p. 399).

If content-area teachers are to effectively assimilate literacy instruction into their repertoires, they need models to follow. As a model, Mrs. Baker shared literacy strategies and activities, demonstrated effective instruction, and led Mr. Stine and Mrs. James in reflective conversations about past and future lessons.

\section{Team-Teaching}

Classroom observations and teacher interviews also revealed that team-teaching is a thread that connected both Mr. Stine and Mrs. James with Mrs. Baker. The atmosphere in each classroom, when the content-area teacher and the coach were present, was one of camaraderie and even fluidity. In many instances, it was difficult to delineate who was the classroom teacher and who was the "guide on the side." Both teachers and their students appeared comfortable with the teaming aspects of the classroom relationships. 
Mr. Stine described his experiences with Mrs. Baker as the first time he has teamtaught in his 18 years in the classroom. He did share that he was hesitant at first, as he has always had deep feelings of personal responsibility for his classroom and his own teaching. But, he agreed that working with a coach, whether in person or through e-mail, has given him a way to bounce ideas and to expand on critical content.

Mr. Stine related the example of the Holocaust unit that I observed with his $10^{\text {th }}$ graders. He said that he has taught that unit every year since his first, all in the same school; however, he noticed that each year his students became less and less affected by the horror of the Holocaust events. Mr. Stine explained that he was searching for a way to emotionally connect 15 - and 16-year-olds to events that occurred over two generations ago. His ability to discuss this with Mrs. Baker led to the use of the Holocaust journal project and gave him a way to infuse reading and writing while simultaneously connecting to student emotions. The team-planning and teaching that occurred in this unit solved a problem that he has grappled with for several years.

My time in Mr. Stine's classroom revealed a professional, yet relaxed relationship between teacher and coach. Mrs. Baker seemed comfortable to add comments, explanations, and, in some cases, personal experiences that supported the instruction. Her addition of comments on her time spent in Germany during college and her experiences on a family trip to the Holocaust museum were critical in moving the students to a deeper understanding of the events being discussed. In several of the team-teaching situations, Mr. Stine and Mrs. Baker seemed to effectively feed off each other's energy. Mr. Stine said, "The students seem to respond to our teamwork. They find us more believable when we reinforce each other." 
In Mrs. James's classroom the team-teaching was even more seamless. In fact, as a school administrator and a veteran observer of teaching behaviors, I was often in awe of the flow of the instructional interaction. Both Mrs. James and Mrs. Baker seemed extremely comfortable with the two-teacher situation and effectively used mutual support, reinforcement, and humor to deepen student learning. One teacher would be at the front of the class while the other was circulating among the students; a few minutes later the roles were reversed. This happened so often and so seamlessiy that their roles became blurred.

Mrs. James explained her feelings about teaming with Mrs. Baker. "I just love the coaching. It has flowed into team-teaching, true team-teaching. We just work so well together. One pops in and the other pops out." Later, she said it another way, "We tag team. One of us is teaching while the other one 'works the room'." That is exactly how it appeared to me; I could not have explained it more clearly:

Mrs. Baker, too, clarified her trust in the team-teaching aspect of her work. "I really feel strongly that team-teaching is effective. Why? Because I feel that differing perspectives and examples that two teachers can offer to a group of students is beneficial. Also, varying personalities of teachers can help to motivate students or encourage them to engage in the lessons." The students in Mrs. James's classes were very much engaged during my time there. Additionally, the easy banter and camaraderie between their English teacher and the literacy coach gave the class a fun and energetic atmosphere that seemed to meet the needs of junior-high students.

Table 4 depicts examples of team-teaching in the classrooms and references to team-teaching in the interviews. 
Table 4

Team-teaching

Data collected from: $\quad$ Examples

Mr. Stine's classroom Easy, comfortable team-teaching atmosphere. Both professional, yet relaxed - seem to feed off of each other's energy.

Interview with Mr. Stine

"Working with a reading coach is my first real experience with team-teaching in my career."

"The students seem to respond to our teamwork. They find us more believable when we reinforce each other."

Interview with Mrs. Baker "I really feel strongly that team-teaching is effective. Why? Because I feel that differing perspectives and examples that two teachers can offer to a group of students is beneficial. Also, varying personalities of teachers can help to motivate students or encourage them to engage in the lessons."

Mrs. James's classroom

Mrs. J leading the class while Mrs. B up and moving around among students.

Seamless!

These two work so well together. They are the definition of team-teaching.

Mrs. B dictates and Mrs. J writes, "The hyperactive English teacher and the abnormal literacy coach came and conquered."

Interview with Mrs. James

"I just love the coaching. It has flowed into team-teaching, true team-teaching. We just work so well together. One pops in and the other pops out." 
The teaming aspect of coaching is addressed at various levels in the literature. Showers (1985) and, later, Showers and Joyce (1996) speak about coaching teams and the value of shared experiences in the craft of teaching. In the earlier article Showers says, "Coaching is as much a communal activity, a relationship among seeking professionals, as it is the exercise of a set of skills and a vital component of training" (1985, p. 43). In their 1995 book, Joyce and Showers summarize their chapter titled "The Design of Training and Peer Coaching" with the following statement:

Many believe that the essence of the coaching transactions is in the offering of advice to teachers following observations. It is not. Teachers learn from each other in the process of planning instruction, developing the materials to support it, watching each other work with students, and thinking together about the impact of their behavior on the learning of their students. The collaborative work of peer-coaching study teams is much broader than observations and conference. (p. 125)

Literacy coaching occurs between two teachers, equal in many ways, different in that one has more expertise in the area of reading and writing. The content-area teachers are, however, the experts in their subject areas and in the management of their classrooms. The relationship between the coach and teacher must be one of mutual respect and sharing to be effective. Knight (2004b), in describing the University of Kansas instructional coaching model, says that coaches "work in partnerships to accelerate teachers' professional learning through mutually enriching, healthy relationships" (p. 2) and that they "expect to get as much as they give whenever they collaborate" (Knight, 2004a, p. 37). Neubert and Bratton (1987) even call their model of coaching "'team coaching' because it resembles team teaching. . . The coach and the teacher together plan, execute, and evaluate the lessons" (p. 30).

Teaming is an effective mode of professional development (Guskey, 1991), but Showers and Joyce (1996) found that teacher study teams affect student learning only if 
the actual act of teaching and the material being taught is the focus of the teachers. Irvin (2006), in describing the essential roles and responsibilities of a literacy coach, says that "the roles require teaching skill, depth of knowledge, and the ability to work well with peers" (p. 44). These role requirements also delineate effective team-teaching skills.

\section{Coach as Validator}

Both Mr. Stine and Mrs. James are veteran teachers, Mr. Stine in his $18^{\text {th }}$ year when I interviewed him and Mrs. James in her $10^{\text {th }}$ year in education. Yet both teachers talked to me about the feelings of inadequacy that they sometime had in the classroom. And, both described how Mrs. Baker worked with them in ways that supported their learning without questioning their expertise.

Early in my interview with Mr. Stine, he described his nontraditional entrance into the field of education and the fact that he had returned to a local university just to take the courses he needed for teacher certification. He said the postsecondary institution was very accommodating by allowing him to take whichever education courses fit in a schedule that would allow him to complete the work quickly. Therefore, Mr. Stine told me that he never felt like he had completed a true education program and never felt confident that he was a good teacher.

"Having Sue in my classroom has helped me to identify what I am doing correctly," Mr. Stine told me. He added that she supports what he already does and, rather than making him feel that he is inadequate, she makes him feel that he is becoming a better teacher.

Mrs. James, in one of our discussions, also expressed doubt as to the strength of her instruction. Although generally not lacking in confidence, this English teacher noted 
that she felt somewhat insecure in teaching grammar. She said she felt that both her high school and her college work in this area were inadequate.

But, Mrs. James seemed to take Sue's strength in this area in stride; in fact, she appeared to enjoy the challenge of learning grammar right along with the students. "So, the students know that Mrs. Baker is the 'grammar queen' and they know that I am learning along with them some of the time, especially on the hard stuff," explained Mrs. James.

Mrs. James also shared that she is learning the reading comprehension material from Mrs. Baker. Working on her PA Reading Specialist certificate, Mrs. James said that Sue has a good sense of what she does and does not know about the reading and that working with the coach has strengthened her knowledge of reading also.

In both classes, I observed several examples of Mrs. Baker's validation of the classroom teachers' instruction. In Mr. Stine's history classroom, she reinforced his efforts as he encouraged the students to empathize with the Jewish children who had to wear the yellow star of identification. Picking up on the value of that mental and emotional exercise for adolescents, Mrs. Baker supported and extended Mr. Stine's questions with her own questions and experiences. In the BHS English classroom, Mrs. Baker validated both Mrs. James's sentence diagramming efforts and her cognitive talk as she explained what she was thinking as she worked. This validation served to support Mrs. James but also modeled the way to support student efforts as they attempt difficult tasks.

Mrs. Baker told me that she has great respect for both Mr. Stine and Mrs. James and for what they know about their subject areas. She used the analogy of a car mechanic 
for the work that she does. "The teachers are the vehicles that convey the information. I simply help them to 'run' better. With these vehicles running more smoothly, students are transported greater distances."

Table 5 depicts evidence of the coach validating the work of the teachers.

Materials written to describe and support the coaching model of professional development caution on the fine line between offering supportive encouragement for change and the perception of supervision. Coaching activities sometimes mirror the activities of a supervisor; specifically, the identification of either weak or strong areas of teachers' knowledge-bases and/or instructional practices could be activities of both a coach and of a supervisor. Toll (2004) notes that "coaching is new to the culture of many schools, and staff members often feel suspicious about claims that the coach is there to help" (p. 6). Both Knight (2004a) and Moffett et al. (1987), in describing specific coaching initiatives, stress that coaches make clear that they are not supervisors and that they do not evaluate teachers. There is no doubt that, to be effective, the coach-teacher relationship needs that guarantee.

But, coaches do need to move teachers toward increased knowledge and expertise in their classroom instruction. Guskey (2003), in his synthesis of professional development research, notes that "the most frequently mentioned characteristic of effective professional development is enhancement of teachers' content and pedagogic knowledge" (p. 9). In a 2004 paper on instructional coaching, the Annenburg Institute for School Reform lays out the strength of coaching as its ability to "build knowledge, improve practice, and promote student achievement" (p. 1). It is critical for the effective coach to have some knowledge to add to the teacher's repertoire but also for that 
Table 5

Coach as Validator

Data collected from: Coach as validator

Mr. Stine's classroom "How would you feel if you were singled out; made to wear a badge of sorts that identified your heritage?" Mrs. B jumps in to add her thoughts several times ... "Keep in mind, how would that make you feel?"

Interview with Mr. Stine "Having Sue in my classroom has helped me to identify what I am doing correctly."

She never makes him feel as though he is not a good teacher-just making good better.

Interview with Mrs. Baker "The teachers are the vehicles that convey the information. I simply help them to 'run' better. With these vehicles running more smoothly, students are transported greater distances."

Mrs. James's classroom

Mrs. J diagrams - she explains her thought process as she diagrams. "Very logical — almost like a math problem where you are plugging in the numbers," says Mrs. B.

Interview with Mrs. James "Working with Sue and the activities in RA has given me a comfort level with many of these strategies. I can just 'do' them now."

"Sue has a good sense of what I know and don't know about reading."

"So, the students know that Mrs. Baker is the "grammar queen' and they know that I am learning along with them some of the time, especially on the hard stuff."

knowledge to be offered in a supportive environment (Neubert \& Bratton, 1987; Poglinco $\&$ Bach, 2004).

Whether teachers are new to the profession or veterans, there is much to be learned; in this case, skills in the development of student literacy. Harwell-Kee (1999) describes coaching as "a continuous growth process for people of all experience levels" 
(p. 28), while Bean (2004) characterized the literacy coach as "someone who provides the guidance or feedback that enables someone else to become more proficient' (p. 96). It seems obvious that, to be effective, the coach must work with a teacher to identify an area of weakness and then work to strengthen that area. But, working with another adult in this capacity could be tricky and certainly requires special skills.

Drawing on leadership literature and her own extensive research, Bean (2004) notes her top three qualifications for literacy coaches. Along with expertise and experience (both needed to provide credibility), she identifies the ability to work with adults as a critical skill. "Coaches must be good listeners, be able to empathize with the teachers, and provide balanced feedback that reinforces excellent teaching behavior and provides ideas for improvement" (p. 98). Bean writes about the coach's roles and describes one as "the coach as a mirror" who "serves to confirm and validate" (p. 113).

Joyce and Showers (1982) describe the coach's "first function" as "an interchange with another human being over a difficult process" (p. 6). Teaching is a difficult process made more difficult by changing expectations; perhaps, the additional pressures of the current state of education are most difficult for the veteran teachers. These teachers need to know that their work is valuable and that the coaching work will build on what is already good.

\section{Coach: Knowledge vs. Personality}

Mr. Stine related very eloquently to me the critical importance of Mrs. Baker's personality in the opening days of their relationship. He told me how, at the first faculty meeting, in the fall of 2005, his principal had introduced Mrs. Baker and asked the teachers to invite her in to work with them. Mr. Stine remembered and relayed, with 
some obvious sarcasm, his perspective on the new coach, "I thought 'Just let me do my job; I know how to read. Why do I need a coach?' I was very skeptical; that was my first impression of the position."

This 18-year veteran went on to tell me that he has never depended on anyone to assist him in his room, not the principal, the language arts teachers, or anyone else. Sadly, he told me that the few times, early in his career, when he sought out help, he found none, at least, none that was effective. So, he said, he did his best to support his students' literacy skills. Knowing that many had difficulty reading, he explained that he deemphasized the textbook and taught mainly by lecture and by telling the students exactly what was most important for them to know and remember.

Mr. Stine went on to explain how he came to know Sue. A week or so after that first faculty meeting he said that Sue sent out an e-mail to everyone and he thought, "Hmm. . . She sounds kind of human." But, he still was not ready to invite her into his room.

Then a few days later, according to Mr. Stine, he was working on an assignment with his American History II class. "I was trying to get across the difficult concept of 'omnipotence' in a lesson on Joseph Stalin. Mrs. Baker appeared at my door and asked if she could help. She was so friendly and had such a nice smile; I thought, "Why not?" He said she suggested a five-paragraph essay and proceeded to explain it. Reluctantly, he agreed and Mr. Stine explained that the results were positive. "The students understood the concept much better."

The second example of collaboration that Mr. Stine related happened later in the first semester. "I always use poems from World War II and was telling her some of the 
poets that I use. Her eyes just lit up." Mr. Stine said he had a compare-and-contrast writing assignment and Sue helped him to build on that.

Mr. Stine said that he worked with the coach rather sporadically last year but that the two of them became deeply involved in a couple of projects. "Sometimes I talked her out of going to BHS so we could work on a unit we had planned." Now, he said their relationship has evolved. "I look at her as a resource, someone to bounce ideas off."

My observation time in Mr. Stine's classroom revealed the results of a relationship that was built over several semesters of work. On the times when I saw the teacher and the coach working together (such as when they read and reflected on the students' Holocaust diaries) they appeared very open and comfortable with each other and with their joint roles. I believe that the trust between the two teachers encouraged the students into collaborative and trusting relationships with each other also.

In Mrs. James's classroom I also saw strong evidence of a trusting relationship between teacher and coach. Possibly becaúse both teachers have similar educational backgrounds, these two teachers worked together with an infectious synergy. In fact, I observed that their relationship was strong enough to support some good-natured joking about their respective skill levels with the various aspects of the grammar lessons. Again, this camaraderie strengthened the trust-level for students in the classroom.

When I asked Mrs. James about Mrs. Baker's strengths, she obviously wrestled with the question in her head. Finally, she concluded, "The coaching works because of her knowledge and her personality. No, it is more because of her personality. If she was not so easy to work with, it wouldn't matter what she knew. But, it works well because of the two together." 
Mrs. James added that, for the two of them, the connection had evolved over almost 2 years. "We have worked together a lot and developed a good relationship. I can read her too. We just complement each other. I am much more vocal in the classroom. I am right on the kids; I talk to them constantly and no one gets away with any rudeness. Sue is not like that with the kids but she has much more education in her head."

In describing how Mrs. Baker had coached her on topics such as the grammar lessons, the reading strategies, and the literature circle activities, Mrs. James said, "Sue's personality and the way she is-it just makes it so easy. You don't feel like you are being watched or criticized."

Mrs. Baker told me that she was not so comfortable with her new coaching role at the beginning. She said that, having been a secondary English teacher, she valued the privacy of the classroom and could feel what it would be like to have an unknown professional come into that space. "At the onset, the primary focus was for me to create a relationship of trust with teachers within the buildings where I work."

Mrs. Baker told me that she occupied her first few weeks reading and learning about effective literacy strategies, attending a week-long Reading Apprenticeship training, and roaming the halls and faculty lounges of her two buildings. She said she also examined student achievement data for the two schools and spent a lot of time listening to what teachers and administrators were saying about students and their needs.

I asked Mrs. Baker to describe how she developed relationships with the two teachers. She said, "I guess a good word would be 'slowly.' The relationships are not immediate, but evolve based on common trust and non-evaluative, non-judgmental talk." Describing how relationships develop into teamwork, she added, "The whole process is 
incremental beginning with simple, short lessons that evolve into more elaborate, detailed plans." She indicated that relationships come first and grow during the common work.

Table 6 shows examples of the personality aspects of the coach's work with the classroom teachers.

Several resources describe characteristics for a successful literacy coach. The International Reading Association, in its 2004 brochure The Role and Qualifications of the Reading Coach, lists five essential elements for a literacy coach to know and be able to do. Fifth on the list is that coaches should be effective at working in classrooms with teachers and "sensitive to the need to develop open, trusting relationships with teachers" (p. 4). In a much more extensive document developed in conjunction with the National Council of Teachers of English, the National Council of Teachers of Mathematics, the National Science Teachers Association, and the National Council for the Social Studies, the IRA (2006) outlines dozens of leadership and content-area literacy standards for coaches. Element 1.2 of the first leadership standard is, "Literacy coaches promote productive relationships with and among school staff' (p. 9). Likewise, PDE's (2004b) job description for a secondary literacy coach lists "Develop positive interpersonal relationships between members of the school building/school district personnel/teams" as the first of seven duties and functions. Finally, the National Association of Secondary School Principals, in its 2005 literacy guide for principals, says it is critical for the literacy specialist to be someone who can work with "all of the personalities of the school team" (p. 47). It is clear that these professional organizations recognize the importance of personal and relationship-building skills in the work of coaching adults. 
Table 6

Coach: Knowledge vs. Personality

Data collected from:

Coach: knowledge vs. personality

Mr. Stine's classroom

Students again seem excited to share their diaries. Lots of openness and conversation among all involved.

Interview with $\mathrm{Mr}$. Stine

"Then Sue sent out an e-mail to everyone and I thought, "Hmm. ... She sounds kind of human."'

"She was so friendly and had such a nice smile; I thought, "Why not?",

Interview with Mrs. Baker

"At the onset, the primary focus was for me to create a relationship of trust with teachers within the buildings where I work."

"I guess a good word would be "slowly." The relationships are not immediate, but evolve based on common trust and non-evaluative, non-judgmental talk."

Mrs. James's classroom

These two teachers appear to have a good relationship. Mrs. J hams it up with a sour face and a dirty look toward Mrs. B. These two could go on the road as a comedy team!

Interview with Mrs. James Sue's personality and the way she is-it just makes it so easy. You don't feel like you are being watched or criticized."

"The coaching works because of her knowledge and her personality. No, it is more because of her personality. If she was not so easy to work with, it wouldn't matter what she knew. But, it works well because of the two together." 
The coach's approach in the early stages of this new initiative is obviously critical to the future success of the endeavor. In 2006, Dole, Liang, Watkins, and Wiggins completed an in-depth analysis of the state of reading teachers in the United States. They recognized the emerging reading coach as one variety of reading specialist and noted that the coach needs "all the qualifications of a reading specialist but also more knowledge and expertise" including "the ability to teach adults and communicate effectively with them" (p. 198). Guiney (2001) says that "the crucial step in coaches' work is how they approach the faculty" and that coaches need to "foster personal trust building" (p. 741). Discussing the system-wide coaching initiative in Boston schools, Guiney describes the unique characteristics of coaches seen as successful and notes that "the aim really is to connect to the teaching soul" (p. 741). Finally, Knight (2006), speaking from his extensive work with the University of Kansas coaching initiative, points to trust as "an essential component of an open coaching relationship" (p. 38). He speaks directly when he says, "Simply put, if teachers like a coach, they usually will try out what the coach suggests. If they don't like the coach, they'll even resist helpful teaching practices" (p. 39). Coaching is not a popularity contest, but it does require foundational relationships that, at first, may take precedence over knowledge. 


\section{CHAPTER FIVE}

\section{RESULTS, CONCLUSIONS, AND RECOMMENDATIONS}

\section{Introduction and Purpose}

No one in education can dispute the fact that the expectations of students, teachers, and administrators are growing daily. The pressures for teachers to be more effective with their students have led to an increased focus on professional development. Coaching, as a form of professional development, has gained momentum and is being viewed in many areas as an effective model (Allen, 2005; Diamond, 2006; Dole, 2004; Guiney, 2001; Knight, 2006; Neufeld \& Roper, 2003; Sturtevant, 2002). In the summer 1999 issue of the Journal of Staff Development, the National Staff Development Council lists coaching as one of the "powerful designs" devoted to new approaches to professional learning (Harwell-Kee, 1999). In that issue, Harwell-Kee (1999) says, "Coaching provides a model of respectful collegial reflection about instructional decisions. The benefits are seen in student learning gains, increased teacher efficacy, and increased satisfaction with one's work and the collaborative culture found in the school" (p. 28).

In the fall of 2005, the Countryside School District (CSSD) hired a literacy coach to work with the teachers in its two small junior-senior high schools. The coach was given the responsibility of moving secondary teachers toward a greater understanding of the reading comprehension needs of their students. The coach was not limited to any 
particular strategies, but was provided training in the Reading Apprenticeship (RA) model.

In this study I attempted to determine if working with a literacy coach had increased secondary teachers" perceptions of their effectiveness in the role of "reading" teacher in their classrooms. Given the long history of isolationism and content-area specificity among high-school teachers, I assumed that convincing secondary teachers that they can and should support a school-wide literacy initiative would be a challenge. Teachers' perceptions, how they think and feel, about their interaction with and their resulting instructional successes as a result of working with a literacy coach are critical indicators of the possible strength of the program.

In this chapter, I will briefly review my methodology and the data collected in my study. I will discuss the results of my research and make some concluding statements about what I found. Finally, I will offer some recommendations for coaches, teachers, school administrators, and other researchers who might be examining the concept of coaching as a form of professional development in their own schools or school districts.

\section{Methodology}

Using purposeful sampling, I identified two teachers who worked closely with the literacy coach in her first 2 years in that role in CSSD. I then used a qualitative case study design for my research; I collected data from classroom observations, interviews of both teachers and the coach, and artifacts from the classrooms and from activities related to the classes I observed. Having collected, typed, and organized the data, I looked for themes across the two classrooms and the three interviews; in addition, I looked for connections to the current literature on coaching. By using data tables, I was able to 
uncover, organize, and analyze five themes that were reflected across my research. I then tied these themes back to the research questions and the literature on coaching.

\section{Results and Discussion}

I addressed three research questions in my classroom observations and in my interviews with the teachers. In the following discussion, I will review my research data, with its embedded themes, to answer the research questions:

1. What literacy practices/teaching strategies are the teachers using with students?

2. How do teachers feel about the literacy work they are doing?

3. How do teachers and the literacy coach perceive their relationships with each other?

\section{Literacy Strategies and Teaching Practices}

Both Mr. Stine and Mrs. James shared (through classroom demonstration and through discussion in interviews with me) a number of specific strategies and instructional activities that they have adopted since working with Mrs. Baker. These strategies and activities support the increase in student metacognitive activities that are the cornerstone of the Reading Apprenticeship initiative.

The two teachers in my study were very open to working with the literacy coach and to the strategies and practices that she suggested. Their personal and professional interests in reading, language, and word study made them ideal candidates for literacy coaching partnerships. 
More importantly, both teachers indicated that literacy instruction has been integrated into their teaching. This is a direct result of the layered activities of the coaching model. The coach introduced the student literacy activities and assisted the teachers in learning how to select and use appropriate literacy strategies. Additionally, she modeled those strategies; then, she team-taught with the teachers; and, finally, the coach remained in the schools and available to support and validate the teachers as they continued to use and refine literacy strategies. The teachers and coach built collaborative relationships that set this type of professional development apart from the traditional workshop model.

In Mr. Stine's classroom, I observed him using daily journals to help students make personal connections to their readings and the classroom lectures on World War II and the Holocaust. These "self to text" and "self to world" connections are two of the three ways that RA strategies focus on helping students to make meaning from contentarea reading (Schoenbach et al., 1999). Students were given the name of either a teenage victim or a survivor of the Holocaust and were instructed to read a short biographical sketch of that person. Each student then assumed the role of that teen and, using classroom notes and textbook material for reference, wrote a daily journal. Peer reading and discussion of the journal entries gave students further "self to other" connections and an opportunity to discuss vocabulary and concepts related to the Holocaust. Schoenbach et al. (1999) say that these types of activities provide the necessary social context for learning while also deepening understanding and giving a purpose to reading. The connections students made also encouraged them to read further on Holocaust topics. 
Mrs. Baker shared with me her excitement when several students showed interest in reading library books that are the diaries and memoirs of actual Holocaust survivors.

Mr. Stine talked about the concept of working with the coach to learn literacy instruction. He referred to another writing assignment that he and Mrs. Baker developed last year to support his World War I unit. He described his search for a project that would help students make a deeper connection to their reading and his lack of self-confidence in designing and grading a writing project. Mrs. Baker came up with the essay topic and rubric that ties directly back to the language arts curriculum, the state writing standards, and helps student connect to their learning.

Mr. Stine explained, "Sue suggested we do a five-paragraph essay on the topic-I was skeptical but she said, "Would you like me to come in and help?"'

This is a perfect example of the coach acting as the leader and professional developer as she responded to a literacy need in the classroom. But, the critical part of this conversation came when Mr. Stine talked about how he felt after the project was over. He explained, "For instance, do I need her to come back and help me with the fiveparagraph essay? No, my training wheels are off with that one. Now we can work on new ideas to enrich other units."

Likewise, in describing another literacy strategy and the release of control back to the classroom teacher, Mrs. Baker referred to the war poetry, double-entry journals that she and Mr. Stine worked on last year. She said, "They simply appeared this year without any request for my help. All I had to do was walk past the display and smile."

Mrs. James told me that working with Mrs. Baker has actually made her now feel like a reading teacher. Because of her love of reading, her language arts background, and 
her recent involvement in a reading specialist certification program, Mrs. James needed little convincing to infuse more literacy strategies into her classroom.

In speaking of the reading strategies, she said, "Some I have been using for a long time; others I have learned through Sue and RA. Many are old strategies with new names. The big difference is now I understand how many of the reading strategies help students comprehend what they read. Working with Sue and the activities in RA has given me a comfort level with many of these strategies. I can just 'do' them now. I can integrate them into all my classes. I use them all day long, every day."

"Read-alouds" and "think-alouds" are RA strategies that assist students in making meaning of text. Schoenbach et al. (1999) talk about using these metacognitive strategies to make meaning of text and to make the invisible visible. I observed many instances of these strategies being used in Mrs. James's classroom by both Mrs. James and Mrs. Baker. The two teachers, as they team-taught, were constantly asking students "Why do you think that?" and "Can you explain?" Mrs. James repeatedly gave students a chance to write their thoughts or explain to a partner before asking them to give an answer. These are comprehension strategies that, once they become embedded in students' reading lives, will assist them in dealing with the increasingly complex text of classrooms.

In 1982, Joyce and Showers noted that

one of the major functions of the coach is to help 'players' to 'read' the responses of the students to make decisions about skill training and how to adapt the model. This is especially important in the early stages of practice when teachers are concerned with their own behavior and it is difficult to worry about the students as well. (p. 7)

This explains perfectly what I observed in Mrs. James's room much of the time. Mrs. James had the basic background and understanding of the literacy strategies. What she lacked was the practice using them and the confidence that she was able to use them 
effectively. She actually needed very little modeling; what really helped her was teamteaching and having Mrs. Baker in the room to assist in gauging student response. Mrs. Baker could then validate Mrs. James's instruction and the student learning and, if needed, collaborate to make adjustments.

Both classroom teachers demonstrated competence and confidence in their content areas but expressed doubts about various areas of literacy instruction. This is not unexpected as few postsecondary teacher-training programs include instruction in the support of reading and/or writing. Mrs. Baker was coaching Mr. Stine and Mrs. James as they accepted and practiced new teaching responsibilities, and both looked to Mrs. Baker for validation that they were doing good work. As the coach gave her approval to their literacy work, these two teachers felt capable of making that new instruction part of their on-going repertoires.

From their extensive research on staff development, Joyce and Showers (1995) drew three conclusions. They concluded that teachers must have time and opportunity to practice the new skills; they will require more training for new content than for relatively familiar content; and, if transfer of the training is the goal, the staff development must include a process of support and collaboration (p. 113). Coaches provide the opportunity for skill development and reflection on those efforts that is so critical in promoting real change efforts. My research with Mrs. Stine and Mrs. James indicated that, for a wide variety of literacy instruction and strategies, the training had transferred to actual practice. This was likely a result of the effective inclusion of all three pieces of the training puzzle. 


\section{Teachers' Feelings About Literacy Work}

Teachers' work is student learning; if students learn, teachers feel productive, successful, and encouraged to continue teaching. If students are not successful, teacher morale suffers; in simple terms, this is why the student assessments mandated by NCLB are so distressful to many educators. It certainly follows that professional development resulting in increased student learning, via more effective instruction, will foster positive feelings for teachers.

Each of the classrooms where I observed was language-rich, both in the physical setting (bulletin boards, posters, mobiles, teacher notes, etc.) and in the speech and vocabulary used by the teachers. Both classroom teachers indicated to me their strong reliance on oral language and extensive conversation with their students. Both placed high value on the written and spoken word and, therefore, were prime candidates for further training in the use of literacy skills. I believe that both Mr. Stine and Mrs. James were already attempting to strengthen the reading, writing, and comprehension skills of their students. Their recognition of the need for this instruction and the value they already placed on literacy made them open to both the coaching initiative and to my request to include them in my research.

In many instances the coach remained the "expert" and modeled the skills and behaviors designed to further strengthen the literacy skills of the students in the two classrooms in my study. Mrs. Baker was constantly honing her knowledge base as she researched and developed relevant literacy strategies and activities to support the curriculum in each classroom. 
In both Mr. Stine's and Mrs. James's classrooms, I observed students who were engaged in and excited about reading and writing activities. And, in interviewing the two teachers, I found veteran professionals who were excited about their recent instructional endeavors.

Once Mr. Stine's students had begun the Holocaust diaries, I saw a definite increase in active student participation. This is evidenced by the following personal comments in my field notes:

"Students appear to be getting into the idea of writing in the diaries. I can gradually see more interest. More students sitting up, leaning forward, etc."

"The room is abuzz with activity! I am so pleased and excited to read the diaries. The students seem pleased that I want to read them and are very willing to share. The two I read are very good and the boys are fun to talk with."

"Students around me are discussing posters due Wednesday-one girl is describing what she has done-I guess hers is finished and the boys want to know what to do.... Students again seem excited to share their diaries. Lots of openness and conversation among all involved."

The writing assignment led to a depth of student involvement in the history of the Holocaust that even Mrs. Baker did not imagine possible. On several occasions, she shared with me her excitement and amazement at the extent of student participation in the project. Mr. Stine shared with me that his goal of having his students "feel" the horrors of the Holocaust was realized and that he knew they had learned much more than dates, places, and names. 
Likewise, my time in Mrs. James's room yielded some observations that indicated student interest and learning. While observing a difficult lesson on conjunctions (not the most stimulating of topics!), I made the following personal comments in my field notes:

"Good rapport-bantering — between Mrs. J. and Mrs. B. This really keeps the seventh graders engaged."

"Good integration of vocabulary words into grammar lesson. I think the students are getting it."

"Student: 'I got it!' before Mrs. J. is done. Wow!"

Mrs. James was excited when she described to me her satisfaction with using the many literacy strategies that she now routinely includes. "The students can see the results. And, like I said, I talk to them all them time. 'Did that help you remember? Do you understand better when you do that?' We talk about what works for them and how to use the strategies to help them understand better. I think the key is to get the kids thinking-that's the whole metacognitive thing."

Joyce and Showers (1982) call the lack of teachers' "interpersonal support and close contact with others in the context of teaching" a "tragedy" (p. 7). Both Mr. Stine and Mrs. James talked extensively about their enjoyment of the teaming aspects of coaching. Comments like, "The students seem to respond to our teamwork" from Mr. Stine, and "The team-teaching works so well on so many levels" from Mrs. James are just a sampling of their feelings about this aspect of working with a coach.

In the classrooms, I saw much evidence of this teaming and its results for students. Mr. Stine told me that, for the first time in his 18-year career, he has someone to brainstorm with and that the sharing has resulted in solutions to perennial instructional 
issues. Likewise, Mrs. James talked about the benefits from teaming with Mrs. Baker. She mentioned the enjoyment of having someone who complements her content-area weaknesses but also observed that two teachers working in tandem is an added benefit to students.

Mr. Stine and Mrs. James also indicated satisfaction with the validating aspects of working with a literacy coach. Again, both teachers already realized the need for additional literacy instruction, but each had reasons for doubting his/her ability to effectively serve student needs in that area.

"Having Sue in the classroom has helped me to identify what I am doing correctly," noted Mr. Stine. He went on to say that he believes he is now doing a better job in his content area as well as doing his part to support student comprehension growth.

Mrs. James indicated that, although she continues to learn from Mrs. Baker, her confidence in what she is doing right has been strengthened. Just using the reading strategies with students on a daily basis has validated her skills and moved her closer to her goal of being a reading teacher.

As Bean (2004) notes, most content-area teachers are doing a good job with students, but the recent focus on teaching reading in all classrooms had caused them to doubt their abilities. Reading strategies can, and should, be integrated into content instruction. A major role of the coach is to recognize where that is already being done, build on those teacher skills, and provide reinforcement to the teachers.

\section{How Teachers and the Coach Perceive Their Relationships}

The two classroom teachers I interviewed indicated satisfaction with the coaching initiative as it was progressing in their classrooms. Quite clearly, the teachers involved in 
my research were satisfied that their relationships with each other resulted in positive changes in instruction. As their work together progressed, their personal and professional relationships evolved. After 2 years of working together, they reported comfort levels that included an increase in independence for the classroom teachers, a decrease in the amount of support provided by the coach, and relationships that involved regular communication and collaboration on an as-needed basis. Again, this fulfills the expectations of Joyce and Showers's (1995) three conclusions about successful coaching experiences.

Mr. Stine characterized his relationship with Mrs. Baker as "more formal to begin with" but said that it "has evolved" and is "now more amicable, casual." He described their current status in this way: "I believe that we have a good thing going. Now I don't bother her when I can do some reading strategy or other on my own. But, I know I can email her or stop her in the hall if I have a question. Lots of times I just want to run something by her."

Mrs. James was likewise positive about her professional relationship with Mrs. Baker. At the close of our formal interview, she characterized their on-going work this way: "We are just so much alike—we each have our own strengths but we complement each other. It just feels so natural. I can't imagine not working with her."

Through modeling, team-teaching, and validating the work of the content-area teachers, the coach nurtured the collaborative relationships that I observed in my study. Both Mr. Stine and Mrs. James indicated that they felt supported and that their work was validated by Mrs. Baker. 
But, in addition, both teachers made strong statements about the friendly and outgoing personality of the coach. According to these teachers, the personal qualities of the coach were definitely a factor in her work. If the coach's knowledge base or instructional suggestions had been of poor quality, the coaching would have been less successful; but, clearly, these two teachers' initial responses to the coaching initiative were based on Mrs. Baker's personality.

Mr. Stine told me that, at the onset of the coaching initiative, he was not at all interested; his years of working solo had convinced him that his was the most efficient way to teach. But, Sue's "friendly" demeanor, her "nice" smile, and her persistent communication finally persuaded Mr. Stine to open his door and allow her into his classroom. He had no idea whether or not she had anything valuable to offer him, but the relationship began because Mrs. Baker sounded "kind of human." Without that human element, Mr. Stine and his students would likely never have taken the Holocaust unit, and a number of other units, to the level that they did.

Mrs. James was also decisive about the value of Mrs. Baker's personality. Speaking of that quality, she said, "If she was not so easy to work with, it wouldn't matter what she knew."

A number of professional organizations (IRA, 2004, 2006; National Association of Secondary School Principals [NASSP], 2005; PDE, 2004b) and researchers (Dole et al., 2006; Guiney, 2001; Knight, 2006) recognize the necessity for relationship-building skills in coaching. A coach is not an evaluator, nor, in the case of CSSD, was it required for teachers to collaborate with the coaching initiative. As voluntary participants, the teachers were definitely influenced first and foremost by Mrs. Baker's personal qualities. 
Likewise, Mrs. Baker realized, from her reading of coaching literature and from her personal experience, that she would need to approach teachers slowly and with care. Having worked as a secondary English teacher for 9 years, she knew the sanctity of the secondary classrooms and proceeded with extreme caution.

"The relationships are not immediate, but evolve based on common trust and nonevaluative, non-judgmental talk," noted Mrs. Baker. She went on to stress that, as a new coach, even though she was working in a district where she was known and respected, she had to move "slowly."

Mrs. Baker indicated satisfaction and pride as she told me how Mr. Stine and Mrs. James have become building leaders in the teaching of reading strategies in their classrooms. She described how her relationships with these two teachers have grown from coach-teacher to more teacher-teacher relationships. Mrs. Baker noted that the instructional strategies that they developed with her are now integrated into their teaching and that she "checks in" with them on a regular basis, mostly to see if they need anything from her. "I will go in and team-teach with Mr. Stine during the Holocaust unit but I know that, if I could not be there, he would do just fine on his own. The same is true for Mrs. James; I almost feel like she could do my job."

\section{Conclusions}

Determining student gains from coaching, or any single professional development activity, will take careful analysis and many years of data; additionally, school culture is not only dependent on a great variety of factors but also slow to change. However, increased teacher efficacy and work satisfaction can be determined fairly quickly using observation and interview methods. 
Eisner (1998) says that qualitative inquiry allows us to create descriptive text which, when well-written, gives others the opportunity to experience what the writer/researcher has experienced (p. 22). He further notes that "to know what schools are like, their strengths and their weaknesses, we need to be able to see what occurs in them" (p. 22). I hope that my foray into these two classrooms and descriptions of the coaching work occurring in them will allow other interested educators to "see" what can happen inside schools and classrooms.

The information I collected in the classrooms of Mr. Stine and Mrs. James and during interviews and incidental conversations with the two teachers and the literacy coach yielded valuable perceptual data. These classroom stories are real-time indications of how coaching is working in one school district and may indicate how it can work in others. The data collected and the results gleaned can be used to design and monitor additional coaching scenarios in CSSD and elsewhere.

\section{Recommendations}

My research resulted in several implications for future use and study of the coaching model in secondary classrooms. These implications can be categorized as relevant to literacy coaches and those interested in that position, to secondary contentarea teachers, to school administrators, and to future researchers.

\section{For Literacy Coaches}

Roller (2006) reported on the IRA's 2005 survey of reading/literacy coaches in the United States noting that almost $90 \%$ of the respondents had the word "coach" in their title. Additionally, she reported that only $17 \%$ of the respondents worked at the 
middle-school level, while even fewer, 7\%, worked in high schools (p. 2). Working as a literacy coach at the secondary level presents a number of challenges that are well summarized by Sturtevant (2002) when she says, "Secondary school literacy coaches must be highly regarded by content area teachers. They must have an intimate knowledge of the secondary school culture and student, as well as an understanding of the stresses and dilemmas of the secondary content teacher" (p. 12). In CSSD, the coach was a veteran secondary teacher who had previously worked in the district and had a reputation for being excellent in the classroom; those characteristics, I believe, yielded her valuable experience as well as credibility.

In addition, coaches are expected to work successfully with students and teachers in classrooms. The IRA took the lead in defining the role of a reading coach at the secondary level and has made a number of strong statements in support of coaching, most notably the publication of their Standards for Middle and High School Literacy Coaches (2006). In that document, the IRA stated, "Though student learning and growth are the eventual goals of all coaching programs, the immediate need is to focus the coach's role on adult learning" (p. 44). Bean, Cassidy, Grumet, Shelton, and Wallis (2002), reporting on the IRA's earlier 1996 survey of reading specialists, likewise stated that "reading specialists need to understand that they are expected to work successfully with students and other adults in a collaborative venture" (p. 740). Several articles in the IRA publication, Reading Today, also mentioned this aspect of coaching. Dole et al. (2006) say, "The ability to teach adults and communicate effectively with them should be an important job requirement for every reading coach" (p. 198), and Shaw, Smith, Chesler, and Romeo (2005) reported that "the 2003 standards [for reading professionals] now 
require that graduate candidates preparing to be reading specialists must actually demonstrate their ability to assist and support classroom teachers and paraprofessionals through pre-professional experiences in literacy coaching" (p. 6). My research strongly supports this requirement. Aspiring coaches should have experiences that prove their ability to collaborate effectively with adult peers.

Finally, for those who can meet the above requirements, coaching may be a viable alternative providing both a challenge and the opportunity for career advancement. The challenge of this position is undeniable. Mrs. Baker described her position this way: "It feels like my job description is being re-written every day, and my role is being revised based on several factors including new research in the field, changing student populations, differing faculty needs, and continuously redefined educational mandates. Pretty much, I go and do what is needed, but I also have the role of determining the needs." It its 2006 Best Practice Brief, the IRA noted that "in the past, career options took good teachers out of the classroom" (p. 2). Now, the literacy-coaching initiative gives good teachers an opportunity to experience some of the independence and responsibility of administration while remaining closely connected to the classroom.

\section{For Teachers}

There are, of course, major implications for classroom teachers who are either considering or preparing to work with a literacy coach. First and foremost must be the understanding of the value of literacy strategies in all secondary content areas. Strong statements supporting the teaching of reading across all content areas have been made by the IRA (2006) when that organization combined with four major professional groups to publish Standards for Middle and High School Literacy Coaches, and by the National 
Association of Secondary School Principals in its 2005 publication Creating a Culture of Literacy: A Guide for Middle and High School Principals. The second document stated, "One of the best strategies for guaranteeing that students meet tough academic standards is to assure that all teachers are skillfully integrating literacy strategies into daily instruction" (p. 12).

A second implication for content-area teachers is the understanding of the role of the literacy coach and the expectations that the coach will have of them. Secondary teachers are, unfortunately, used to a culture of isolationism. Content-area teachers must be willing partners in the literacy initiative and must be prepared to eventually assume the role of reading-in-the-content-area teachers. This is labor-intensive work if student learning is to increase significantly. Guskey (1991) says, "Any change that holds great promise for increasing individuals' competence and enhancing their effectiveness is likely to be slow and require extra work, especially when beginning" (p. 244). As my research indicated, this literacy work demands extended time, relationship-building, and collaboration on the part of the teacher and the coach. "Because a coach must build a good working relationship with the teacher, the latter must help to set the agenda" (Allen, 2005, p. 8).

While the literacy work and the increasing demands for increased student performance may, at times, seem overwhelming to the classroom teachers, the coaching relationship has the potential to provide professional support rarely experienced by secondary teachers. Both Mr. Stine and Mrs. James expressed their appreciation of the value of the coaching relationship. Over 25 years ago, in an early explanation of the benefits of coaching, Joyce and Showers (1982) said, "Teachers' lack of interpersonal 
support and close contact with others in the context of teaching is a tragedy. Coaching reduces this isolation and increases support" (p. 7).

\section{For Administrators}

Public school administrators feel the pressure of NCLB more than anyone else in schools; after all, the federal law places blame for students' lack of achievement directly on the shoulders of the administrators. For secondary principals, the remediation of students who have failed to meet proficiency standards for a number of years seems impossible. Allen (2000) says that "schools should capitalize on the resilience of students who persevere in school despite inadequate help for their reading problems" (p. 8). He and many others see literacy instruction as a viable solution to student failure at the secondary level.

Professional development is the responsibility of school administrators and there is no lack of support for coaching as effective professional development. Killion (2003), speaking on behalf of the National Staff Development Council, described the most effective professional development for literacy as "typically a multiyear effort of planned, coherent, and in-depth learning experiences ... including coaching" (p. 7). At the 2006 IRA Reading Research Conference, Walpole and McKenna described the professional development that most meets teacher needs as "intensive, ongoing, site based, and firmly nested in day-to-day teaching and learning" (p. 1). Finally, the National Council of Teachers of English (NCTE), in its 2006 Principles of Adolescent Literacy Reform, posits that "professional development reaches its ultimate stage when teachers feel comfortable supporting others in learning a new approach" (p. 90). Administrators are wise to 
consider teacher collaboration and some form of coaching as they plan professional development.

If administrators do use coaching as a means to provide effective professional development, they should know how critical their attention is to the program. Showers (1985) said, "The invaluable role of principals in facilitating coaching programs cannot be too strongly emphasized" (p. 48), and Knight (2004b) noted that "principals significantly increase coaches' effectiveness when they collaborate with coaches" (p. 3). Neufeld and Roper (2003) gave administrators more specific instruction when they directed them to "provide clear, explicit, and continuing support for the coaching program. Without question, the most important condition for successful coaching is district support for coaches' work" (p. 16).

Finally, administrators should be proactive in making decisions about who should coach. My research clearly demonstrated that the personality of the coach combined with her expertise led to her success in working with two classroom teachers. The Annenberg Institute's 2004 statement on instructional coaching noted that "districts that put careful thought into defining the role of coaches, selecting them, and ensuring their learning are helping their coaches to achieve the greatest success" (p. 12). Neufeld and Roper (2003) observed that "most districts have found that they need to "grow their own' coaches and sustain them with relevant, ongoing professional development" (p. 11). That was the case in Countryside School District and this research supports the idea that coaches should be respected by their peers. 


\section{For Researchers}

There is great need and opportunity for further research in the area of literacy coaching and coaching in general. In 2001, Quatroche, Bean, and Hamilton reviewed the research on the role of the reading specialist and concluded that "the paucity of the research related to the role of the reading specialist was striking" (p. 289). Dole (2004), in examining the continued changing role of the reading specialist, noted that "other than the work of Joyce and Showers, there is little research on reading coaches to help administrators and specialists make important decisions about how to use reading coaches" (p. 466). Neufeld and Roper (2003) noted that "no one, as yet, has proven that. coaching contributes significantly to increased student achievement. Indeed, there are scant studies of this form of professional development and how it influences teachers' practice and students' learning" (p. 1). They went on to say that "without some links between coaching, teacher learning, and student achievement, it is difficult to justify the expense of coaching, especially in times of tight budgets when districts may be tempted to return to older, large-group forms of professional development" (p. 24).

In 2006 the IRA reflected that "evaluations of the coaching model or systematic study of factors affecting the implementation of coaching have not yet been carried out" (p. 35). Yet, in the same document, the IRA recommended that "given the current demands of No Child Left Behind policies and the ever-present achievement gap in middle and high schools around the United States, waiting for that body of research to be produced before committing to coaching is neither feasible nor wise" (p. 45). A number of recent studies on various aspects of coaching (Nowak, 2003; Rainville, 2007; Smith, 2006) decry the lack of research on coaching as a form of professional development. 
My case study approach to the examination of one coaching initiative showed that the use of a literacy coach to support the professional growth of secondary content-area teachers can be very effective. However, more studies of this type are needed to determine if coaching is effective with all, or even most, teachers. And, of critical importance is the need for longitudinal studies that examine student achievement related to coaching initiatives. 
APPENDIX 
APPENDIX A

LITERACY COACH DESCRIPTION 


\section{Countryside School District \\ Job Description}

\section{Secondary Literacy Coach}

developed April 2005

\section{Qualifications}

1. PA Reading Specialist Certificate

2. Master's degree strongly preferred

3. Strong literacy background

4. Minimum of five years teaching experience, including experience with diverse student population

\section{Skills:}

Commitment to continuous professional development

Ability to use technology to analyze and manipulate data and to integrate into instruction Excellent interpersonal, presentation, organizational, and oral/written communications skills

Ability to work independently

Excellent analytic and inferential skills

Demonstrated ability to work collaboratively with professional staff on instructional improvement issues

Ability to provide professional development workshops

Classification: Professional Employee-STEA contract

Reports to: Principal

\section{Summary of job:}

Provide job embedded professional development for the purpose of coaching teachers to improve literacy instruction and assist teachers in deepening their own content knowledge and pedagogy. The Secondary Literacy Coach will work primarily with teachers, both one-on-one and in groups, with the ultimate goal of improving the educational achievement of students through higher level reading and comprehension.

\section{Essential functions:}

1. Assume the role of a facilitator who provides assistance and guidance as teachers develop a repertoire of literacy strategies.

1.1 Plan, coordinate and lead the implementation of school-wide reading interventions.

1.2 Identify support services and other resources.

1.3 Assist with the development, planning, and presentation of building and district level professional development. 
2. Team teach with teachers

2.1 Provide information on how to integrate literacy instructional time into contentarea curricula

2.2 Help teachers transfer newly acquired instructional practices into their classrooms

2.3 Observe classroom instruction to improve teaching and provide critical feedback

2.4 Demonstrate effective instructional strategies

2.5 Help teachers analyze student work and identify students' level of understanding and proficiency.

2.6 Assist in the development and administration of student assessments.

2.7 Work with students individually and in groups

3. Assume the role of mentor, share knowledge and experience with colleagues, promote peer collaboration, and connect teachers to best practices through modeling and professional literature.

4. Collaborate with classroom teachers to design and implement instruction that is aligned with the PA state standards.

5. Assist with the identification of school-wide academic performance needs and development of solutions to improve performance.

6. Promote the utilization of research-based strategies in all classes, increasing the knowledge base about literacy instruction.

7. Collect, compile, analyze, and communicate student data, including longitudinal data.

Conduct subject and grade-level planning meetings with teachers to analyze student data and plan for instruction.

Keep current on research and best practices, including participating in professional organizations, attending conferences, and forming collegial relationships with other schools using similar practices.

Collaborate with elementary teachers for transition of students from sixth grade to seventh grade. 
APPENDIX B

COACH INTERVIEW QUESTIONS 


\section{Interview Questions for}

"Teacher Perceptions of their Effectiveness in Supporting Reading Strategies as a Result of Collaboration with a Literacy Coach"

Method: I will interview the Belle and Ward High Schools' literacy coach in an effort to learn her perceptions of the work that she does. I will use the following questions as a framework for the interviews.

1. Tell me about how you came to be a literacy coach.

2. Describe your typical day working as a literacy coach?

3. Describe some activities that you either lead or participate in over the course of a week or two in your position.

4. How has your work evolved as you have done this job of coaching?

5. Describe for me several techniques and/or strategies that you have found successful with students.

6. Why do some strategies work? What do you think are the keys to successful learning strategies for students?

7. Talk about a relationship with a teacher that has worked well for you? How did you come to that relationship?

8. Use a metaphor to describe the heart and soul of your work as a coach --- Being a literacy coach is like...

9. Is there anything else about your experience as a literacy coach that you feel compelled to share with me? 
APPENDIX C

TEACHER INTERVIEW QUESTIONS 


\section{Interview Questions for}

"Teacher Perceptions of their Effectiveness in Supporting Reading Strategies as a Result of Collaboration with a Literacy Coach"

Method: I will interview the two teachers identified by purposeful sampling, one each in Belle Junior-Senior H. S. and Ward Junior-Senior H. S., in an effort to learn their individual perceptions about the ways each supports reading strategies in their content area classrooms since working with the literacy coach.

1. Tell me about your background in teaching reading - in college and/or courses or workshops that you have participated in since your teaching career began.

2. Tell me about the reading strategies that you feel comfortable using with students in your classroom.

3. When did you begin to use these strategies and how did you develop the expertise and comfort level that you have in using them?

4. Coaching is a form of professional development. Tell me about working with a coach as compared to other forms of professional development you have experienced.

5. How often and in what capacity have you worked with Mrs. D. (the literacy coach) over the past two years?

6. Tell me about a typical interaction with Mrs. D.

7. Talk about your relationship with Mrs. D. How did you come to that relationship?

8. Describe for me several reading techniques and/or strategies that you have found successful with students.

9. Why do some strategies work? What do you think are the keys to successful learning strategies for students?

10. Coaching can also be seen as a teaming exercise; in what ways do you and Mrs. D. operate as a team?

11. Describe students' reactions to having two teachers in the classroom? Tell me how it works when Mrs. D. and you are team-teaching.

12. Is there anything else about your experience working with Mrs. D. that you feel compelled to share with me? 


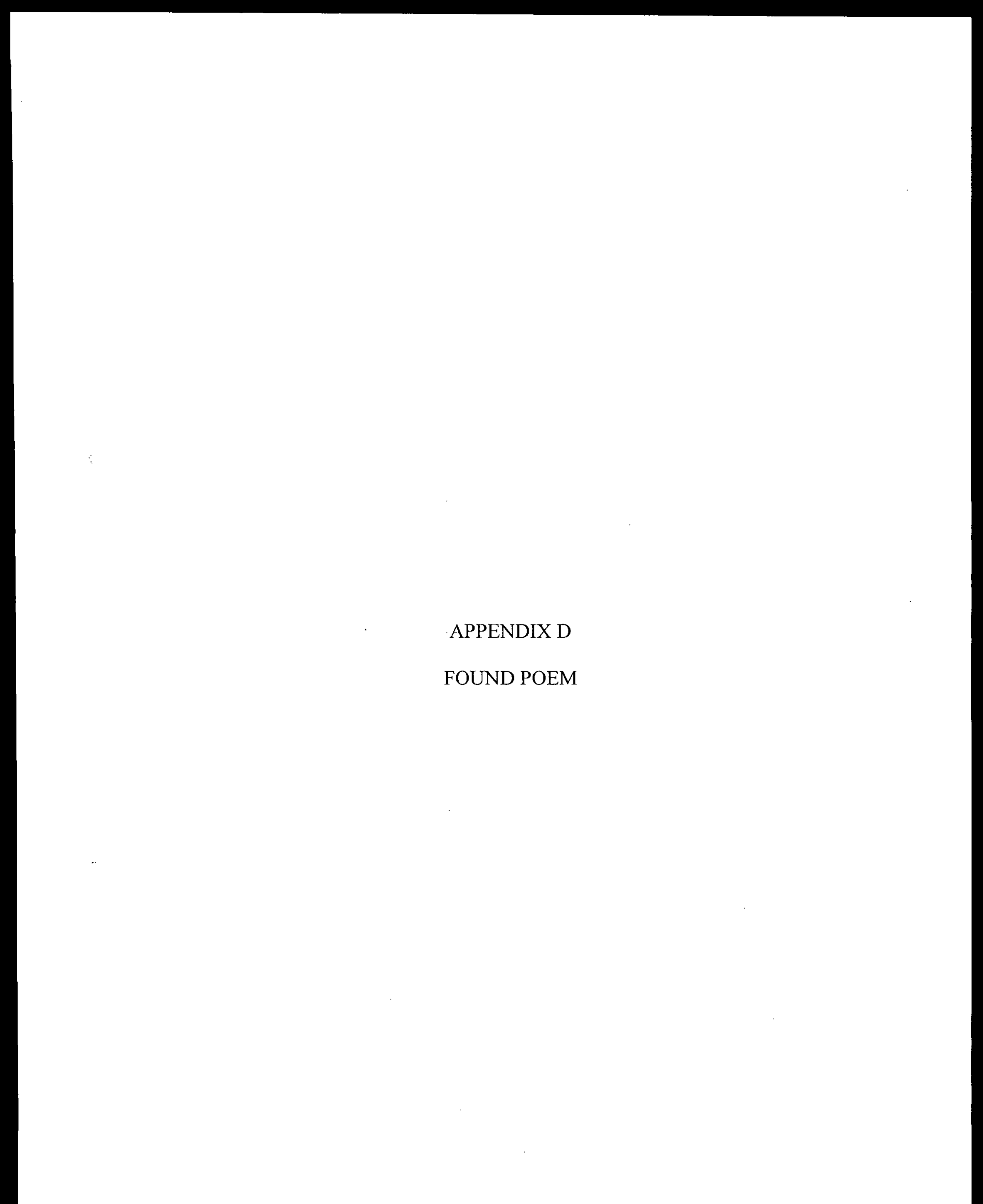


Coaches?

a found poem by

Sharon S. Miller for

LEAD756 Advanced Studies in Qualitative Research

\author{
Coaches? \\ Of literacy? \\ What sense does that make? \\ Just ask them. \\ What do you do? \\ How do you help in schools? \\ How do you help teachers? \\ How do you help students? \\ Literacy coaches? \\ Who are you? \\ What are you? \\ $\mathrm{Hmm}$ \\ I am organized. \\ And flexible. \\ And creative. \\ And energetic. \\ And friendly. \\ And I do everything. \\ Anything. \\ Everything and anything that needs to be done. \\ Any time. \\ Any where. \\ I go and I do. \\ I do it all in schools. \\ I support teachers. \\ New teachers. \\ Veteran teachers. \\ All teachers. \\ I evaluate data. \\ I look for research. \\ I find strategies. \\ I supply resources. \\ I observe. \\ I demonstrate. \\ I run programs. \\ I teach teachers.
}


Students?

They're the ones.

The special ones.

The ones I do this work for.

In the trenches.

With the students.

And the teachers.

That's where I work.

Finding strategies that work.

For the students.

To learn - faster, better, more deeply.

I teach teachers so students can succeed.

Literacy coaches?

Special people.

Special teachers with

Special skills.

Interpersonal skills and

Professional expertise.

They communicate.

They build relationships.

They transmit knowledge.

They are too few.

Find us more literacy coaches!

Hmm. 
APPENDIX E

LETTER TO SCHOOL BOARD MEMBERS 
Sharon S. Miller

999 Oakdale Road

Wild Wood, PA 11111

February 12, 2007

Dear Countryside School District Board of Education Member:

As you know, I am working on a Doctorate of Education in Leadership through Andrews University in Berrien Springs, Michigan. I expect to have my dissertation proposal officially approved within the next week and, at that time, will begin the process of having my research methodology approved by the university's IRB board. By March, I expect to be able to begin my research.

I have attached a copy of my proposal. My dissertation title is "Teacher Perceptions of Their Effectiveness in Supporting Reading Strategies as a Result of Collaboration with a Literacy Coach." My research will be of a qualitative nature; specifically, it will be a case study. I will identify two teachers who have embraced the coaching model of professional development and do in-depth interviews with and observations of those teachers. To identify the teachers to study, I will survey all BHS and WHS teachers using a version of Gene Hall's "Stages of Concern" questionnaire (attached.) This is a 35-question tool used to identify individuals' levels of concern with a new innovation. In addition, I will interview the principals and guidance counselors at the two high schools to determine their perceptions of teachers' involvement with the reading coach. Finally, I will study the daily journals kept by the literacy coach for the past three semesters. I will tally each teacher's name and how many times it is mentioned. These three methods will assist me in choosing the teachers to study. I will study two teachers who have embraced the coaching model most fully and will attempt to assess their perceptions of how working with a coach has affected their work with students.

Elliot Eisner, in The Enlightened Eye: Qualitative Inquiry and the Enhancement of Educational Practice, says that the study of schools or classrooms "can provide the double advantage of learning about schools or classrooms and learning about individual classrooms and particular teachers in ways that are useful to them" (p.12). It is my intention that this research will be valuable for the teachers involved, for the entire district, and for the educational community at large as we all attempt to assess the value of coaching as professional development.

Thank you for your consistent support of efforts to enhance education in CSSD and, especially, for your support of my educational endeavors. I look forward to eventually sharing my research results with you.

Sincerely,

Sharon S. Miller 
APPENDIX F

REQUEST LETTER TO PRINCIPAL 
Sharon S. Miller

999 Oakdale Road

Wild Wood, PA 11111

February 24, 2007

Dear Mr. Jones, Belle Junior-Senior High School Principal:

As you know, I am working on a Doctorate of Education in Leadership through Andrews University (AU) in Berrien Springs, Michigan. My dissertation proposal has been officially approved by the CSSD Board of Education and my AU dissertation committee. I have undertaken the process of having my research methodology approved by the university's IRB board. By early March, I expect to be able to begin my research.

I have attached a copy of my proposal. My dissertation title is "Teacher Perceptions of Their Effectiveness in Supporting Reading Strategies as a Result of Collaboration with a Literacy Coach." My research will be of a qualitative nature; specifically, it will be a case study. I will identify two teachers who have embraced the coaching model of professional development and do in-depth interviews with and observations of those teachers. To identify the teachers to study, I will survey all BHS and WHS teachers using a version of Gene Hall's "Stages of Concern" questionnaire (attached.) This is a 35-question tool used to identify individuals' levels of concern with a new innovation. In addition, I will interview the principals and guidance counselors at the two high schools to determine their perceptions of teachers' involvement with the reading coach. Finally, I will study the daily journals kept by the literacy coach for the past three semesters. I will tally each teacher's name and how many times it is mentioned. These three methods will assist me in choosing the teachers to study. I will study one teacher from each building (BHS and WHS) who has embraced the coaching model most fully and will attempt to assess his/her perceptions of how working with a coach has affected his/her work with students.

I am officially requesting your permission to survey all teachers in your building and, eventually, conduct in-depth interviews and observations of one teacher who has embraced the coaching initiative. I will work closely with you in choosing the times for all research and will ensure that none of my research interferes with student learning.

Elliot Eisner, in The Enlightened Eye: Qualitative Inquiry and the Enhancement of Educational Practice, says that the study of schools or classrooms "can provide the double advantage of learning about schools or classrooms and learning about individual classrooms and particular teachers in ways that are useful to them" (p.12). It is my intention that this research will be valuable for the teachers involved, for the entire district, and for the educational community at large as we all attempt to assess the value of coaching as professional development. 
Thank you for your consistent support of CSSD and, especially, for your support of my educational endeavors. I look forward to eventually sharing my research results with you.

Sincerely,

Sharon S. Miller

I give permission for Sharon Miller to conduct research in Belle High School during the winter and spring of 2007 as outlined in the description above and in her attached dissertation proposal.

Signature

Date

(Please print name.) 
APPENDIX G

ANDREWS UNIVERSITY APPLICATION FOR APPROVAL 


\section{Andrews University}

Application for Approval

Research Involving Human Subjects
Institutional Review Board

Office of Scholarly Research
Tel: $616-471-6360$

Fax: 616-471-6246

Title of the Study: Teacher Perceptions of their Effectiveness in Supporting Reading Strategies as a Result of Collaboration with a Literacy Coach Sharon S. Miller, Leadership student, LEAD899: Doctoral Dissertation Dr. Jim Tucker, advisor

Dr. Shirley Freed, methodologist

\section{Purpose:}

Reading in the content areas can be challenging for secondary school students and, while content area teachers expect students to read and comprehend textbook and other reading material, there is continuing evidence that this expectation is unfulfilled in many classrooms. Secondary teachers typically have little background in the teaching of reading or reading strategies; yet, with reading proficiency the cornerstone of most high-stakes tests, they are increasingly being asked to support the teaching of reading. The use of literacy coaches is one strategy for infusing the teaching of reading skills and strategies throughout the coursework of secondary schools. The purpose of this study is to determine the perceptions of secondary teachers toward their ability to support reading strategies after having worked with a literacy coach. The researcher will use extended observation of two content-area teachers and the literacy coach as they work; interviews with the literacy coach; and interviews with each of the two classroom teachers.

\section{Inclusion Criteria:}

In order to participate in the study the interviewee must be a teacher employed by Countryside School District in either Belle Junior-Senior High School or Ward Junior-Senior High School and agree to having the researcher observe in his/her classroom as well as agree to answer interview questions to the best of his/her ability.

\section{Procedures:}

Interviewees understand that they are participating in a research study and that they will be asked to answer questions during several interview settings. They will have the opportunity to ask questions and receive satisfactory answers before agreeing to participate in the study. The researcher's observations and the interviewees' comments will be recorded and all information shared will be kept confidential through nondisclosure of the interviewees' names and schools. The interviewees will have the opportunity to review all information before the researcher completes the project.

\section{Risks and Discomforts:}

There are no obvious risks involved in participating in this study.

\section{Benefits/Results:}

Interviewees will not receive any direct benefits from participation in this study. It is understood that the results may help educators determine strategies that may positively impact the reading success of secondary students. Information collected during this study will be used in a doctoral dissertation.

\section{Voluntary Participation:}

Participation in the study is voluntary. Participants my discontinue involvement in the study at any time without any penalty or prejudice. There is no compensation in return for participation. 


\section{Contact Information:}

If you have questions or concerns please contact:

Sharon Miller (Doctoral student)

Dr. Shirley Freed (Dissertation committee methodologist)

Phone $570-998-8118$ or

Phone 1-888-717-6247 or e-mail Freed@andrews.edu

e-mail Millers68@hughes.net

Participant's Signature

Date:

Location:

Witness:

Witness:

"I have reviewed the contents of this form with the person signing above. I have explained the potential risks and benefits of this study."

Investigator's Signature

Date: 
REFERENCE LIST 


\section{REFERENCE LIST}

A Nation at Risk: The Imperative for Educational Reform. (1983, April). Retrieved

October 2, 2006, from http://www.ed.gov/pabs/NatAtRisk/risk.html

Allen, R. (2000, Summer). Before it's too late: Give reading a last chance. Curriculum Update. Alexandria, VA: ASCD.

Allen, R. (2005, February). Spread the word: Literacy coaches share comprehension strategies. Education Update. Alexandria, VA: ASCD.

Annenberg Institute for School Reform. (2004). Instructional coaching: professional development strategies that improve instruction. Providence, RI: Brown University. Retrieved November 15, 2006, from http://www.annenberginstitute .org

Auerbacher, I. (1993). I am a star: Child of the Holocaust. New York: Pearson Publishing.

Barone, T., \& Eisner, E. (1997). Arts-based education research. In R. Jaeger (Ed.), Complementary methods for research in educational leadership $\left(2^{\text {nd }}\right.$ ed.) (pp. $75-$ 116). Washington, DC: AERA.

Baumann, J. F., \& Duffy, A. M. (1997). Engaged reading for pleasure and learning. Athens, GA: University of Georgia, National Reading Research Center.

Bean, R. M. (2004). The reading specialist: Leadership for the classroom, school, and community. New York: The Guilford Press.

Bean, R. M., Cassidy, J., Grumet, J. E., Shelton, D. S. \& Wallis, S. R. (2002). What do reading specialists do? Results from a national survey. The Reading Teacher, 55, 736-742.

Biancarosa, G., \& Snow, C. E. (2006). Reading next-A vision for action and research in middle and high school literacy: A report from Carnegie corporation of New York $\left(2^{\text {nd }}\right.$ ed.). Washington, DC: Alliance for Excellent Education.

Blachowicz, C. L., Obrochta, C., \& Fogelberg, E. (2005). Literacy coaching for change. Educational Leadership, 62, 55-58. 
Cassidy, J., Garrett, S. D., \& Barrera, E. S. (2006). What's hot in adolescent literacy 1997-2006. Journal of Adolescent \& Adult Literacy, 50(1), 30-36.

Clandinin, D. J., \& Connelly, F. M. (2000). Narrative inquiry. San Francisco, CA: Jossey-Bass.

Cobb, C. (2005). Literacy teams: Sharing leadership to improve student learning. The Reading Teacher, 58, 472-4.

Dewey, J. (1938). Experience and education. New York: Simon and Schuster.

Diamond, L. J. (2006). Triage for struggling adolescent readers. The School Administrator, 4, 10-14.

Dole, J. (2004). The changing role of the reading specialist in school reform. The Reading Teacher, 57, 462-470.

Dole, J. A., Liang, L. A., Watkins, N. M., \& Wiggins, C. M. (2006). The state of reading professionals in the United States. The Reading Teacher, 60, 194-199.

Eisner, E. W. (1997a). The new frontier in qualitative research methodology. Qualitative Inquiry, 3, 259-273.

Eisner, E. W. (1997b). The promise and perils of alternative forms of data representation. Educational Researcher, 26, 4-10.

Eisner, E. W. (1998). The enlightened eye. Upper Saddle River, NJ: Prentice-Hall.

Ellis, A. K. (2005). Research on educational innovations ( $4^{\text {th }}$ ed.). Larchmont, NY: Eye on Education.

Fielding, A., \& Schoenbach, R. (Eds.). (2003). Building academic literacy: An anthology for reading apprenticeship. San Francisco, CA: Jossey- Bass.

Fielding, A., Schoenbach, R., \& Jordan, M. (2003). Building academic literacy: Lessons from reading apprenticeship classrooms, grades 6-12. San Francisco, CA: JosseyBass.

Fisher, D., Brozo, W., Frey, N., \& Ivey, G. (2006). 50 content area strategies for adolescent literacy. Upper Saddle River, NJ: Pearson Education Publishing.

Fullan, M. (2001). The meaning of educational change ( $3^{\text {rd }}$ ed.). New York: Teachers' College Press.

Glesne, C. (1997). That rare feeling: Re-presenting research through poetic transcription. Qualitative Inquiry, 3, 202-221. 
Guiney, E. (2001). Coaching isn't just for athletes: The role of teacher leaders. Phi Delta Kappan, 82, 740-743.

Guskey, T. R. (1991). Enhancing the effectiveness of professional development programs. Journal of Educational and Psychological Consultation, 2, 239-247.

Guskey, T. R. (2003, April). The characteristics of effective professional development: $A$ synthesis of lists. Paper presented at the Annual Meeting of the American Educational Research Association, Chicago, IL.

Hall, B. (2004). Literacy coaches: An evolving role. Carnegie Reporter, 3. Retrieved June 3, 2006, from http://www.carnegie.org/reporter/09/literacy

Hall, G. E., Hord, S. M., George, A. A., Stiegelbauer, S., \& Dirksen, D. (2006). Measuring implementation in schools: Using the tools of the concerns-based adoption model. Austin, TX: Southwest Educational Development Laboratory.

Harwell-Kee, K. (1999). Coaching. Journal of Staff Development, 20(3), 28-29.

Hobgood, J. M. (1998). Finders keepers: Owning the reading they do. Voices from the Middle, 5, 26-33.

International Reading Association. (2000). Teaching all children to read: The roles of the reading specialist. Newark, DE: Author. Retrieved October 15, 2006, from http:// www.reading.org/downloads/positions/ps1040_specialist.pdf

International Reading Association. (2004, June). The role and qualifications of the reading coach in the United States. Newark, DE: Author.

International Reading Association. (2006). Standards for middle and high school literacy coaches. Newark, DE: Author.

Irvin, J. L. (2006). A resource guide for adolescent literacy. Retrieved March 2, 2008, from http://www.maupinhouse.com/pdf/ResourceGuide.pdf

Joyce, B., \& Showers, B. (1980). Improving inservice training: The messages of research. Educational Leadership, 37, 379-385.

Joyce, B., \& Showers, B. (1982). The coaching of teaching. Educational Leadership, 5, 4-10.

Joyce, B., \& Showers, B. (1995). Student achievement through staff development $\left(2^{\text {nd }}\right.$ ed.). White Plains, NY: Longman Publishers.

Killion, J. (2003). Use these six keys to open doors to literacy. Journal of Staff Development, 24, 10-16. 
Knight, J. (2004a). Instructional coaches make progress through partnership: Intensive support can improve teaching. Journal of Staff Development, 25(2), 32-37.

Knight, J. (2004b). Instructional coaching. Stratenotes, 13, $1-5$.

Knight, J. (2005). A primer on instructional coaches. Principal Leadership, 5, 16-21.

Knight, J. (2006). Instructional coaching. The School Administrator, 4, 36-40.

Krovetz, M., \& Cohick, D. (1993). Professional collegiality can lead to school change. Phi Delta Kappan, 75, 331-334.

Lyon, G. R. (1998). Statement to Committee on Labor and Human Resources, Washington, DC. Retrieved April 3, 2006, from http://www.able.state.pa. us/nclb/lib/nclb/Reid\%20Lyon\%20Statement.pdf

Lyons, C. A., \& Pinnell, G. S. (2001). Systems for change in literacy education: A guide to professional development. Portsmouth, $\mathrm{NH}$ : Heinemann.

Merriam, S. B. (1998). Qualitative research and case study applications in education. San Francisco, CA: Jossey-Bass.

Moffett, K. L., St. John, J., \& Isken, J. A. (1987). Training and coaching beginning teachers: An antidote to reality shock. Educational Leadership, 44, 34-36.

Moxley, D. E., \& Taylor, R. T. (2006). Literacy coaching: A handbook for school leaders. Thousand Oaks, CA: Corwin Press.

National Association of Secondary School Principals. (2005). Creating a culture of literacy: A guide for middle and high school principals. Reston, VA: Author.

National Center for Education Statistics. (2001). Outcomes of learning: Results from the 2000 program for international student assessment. Washington, DC: U.S. Department of Education.

The National Council of Teachers of English. (2006, April). NCTE Principles of adolescent literacy reform. Urbana, IL: Author.

National Staff Development Council. (2001). Standards for staff development. Oxford, $\mathrm{OH}: \mathrm{NSDC}$.

Neubert, G. A., \& Bratton, E. C. (1987). Team coaching: Staff development side by side. Educational Leadership, 44, 29-32. 
Neufeld, B., \& Roper, D. (2003). Coaching: A Strategy for Developing Instructional Capacity. Education Matters, Inc. Retrieved November 3, 2006, from http://www.annenberginstitute.org/images/Coaching.pdf

No Child Left Behind Act, 20 U.S.C. $§ 6301$ et seq. (2001).

Nowak, R. L. (2003). The discourse of literacy coaching: Teacher-coach interactions during a summer school practicum. Unpublished doctoral dissertation, University of Florida, Gainesville.

Pennsylvania Department of Education. (2004a, July 1). Certification staffing assignment: English. CSPG No. 42, Instructional Area Code 3230. Harrisburg, PA: Author.

Pennsylvania Department of Education. (2004b, July 1). Certification staffing assignment: Secondary literacy coach 7-12. CSPG No. 83, Educational Specialist Code 1838. Harrisburg, PA: Author.

Poglinco, S. M., \& Bach, A. J. (2004). The heart of the matter: Coaching as a vehicle for professional development. Phi Delta Kappan, 85, 398-400.

Quatroche, D. J., Bean, R. M., \& Hamilton, R. L. (2001). The role of the reading specialist: A review of research; research suggests that the primary role of the reading specialist is instruction of students with reading problems. How this takes place depends upon the context or setting. The Reading Teacher, 55, 282-294.

Rainville, K. N. (2007). Situated identities, power, and positioning: Inside the practices of three literacy coaches in New Jersey. Unpublished doctoral dissertation, Columbia University, New York.

Rasmussen, L. M. (2005). Relationship between students' reading achievement and the use of a literacy coach for teachers' instructional practices in reading. Unpublished doctoral dissertation, Seattle University, Washington.

Rhoder, C., \& Huerster, P. (2002). Use dictionaries for word use with caution. Journal of Adolescent and Adult Literacy, 45(8), 730-741.

Richardson, L. (2005). Poetic representation. In J. Flood, S. B. Heath, \& D. Lapp (Eds.), Handbook of research on teaching literacy through the communication and visual arts (pp. 232-238). Mahwah, NJ: Lawrence Erlbaum Associates.

Roller, C. M. (2006). Reading and literacy coaches report on hiring requirements and duties survey. Newark, DE: International Reading Association.

Rossman, G. B., \& Rallis, S. F. (2003). Learning in the field ( $2^{\text {nd }}$ ed.). Thousand Oaks, CA: Sage. 
Sandmeier, D. (2005). Accelerating reading achievement: The role of the high school literacy coach. Retrieved March 8, 2005, from http://www.nea.org/ teachexperience/rdk030227.html

Santa, C. M. (2006). A vision for adolescent literacy: Ours or theirs? Journal of Adolescent \& Adult Literacy, 49(6), 466-476.

Schachter, R. (2006). Making reading count. District Administration, 42, 36-40.

Schoenbach, R., Greenleaf, C., Cziko, C., \& Hurwitz, L. (1999). Reading for understanding: A guide to improving reading in middle and high school classrooms. San Francisco, CA: Jossey-Bass.

Schwandt, T. (1999). On understanding understanding. Qualitative Inquiry, 5, 451-465.

Shaw, M. L., Smith, W. E., Chesler, B. J., \& Romeo, L. (2005). Moving forward: The reading specialist as literacy coach. Reading Today, 22, 6.

Showers, B. (1985). Teachers coaching teachers. Educational Leadership, 42, 43-48.

Showers, B., \& Joyce, B. (1996). The evolution of peer coaching. Educational Leadership, 53, 12-16.

Silverman, F. (2006). Struggling readers. District Administrator, 42, 70-71.

Smith, A. T. (2006). The middle school literacy coach: Roles, contexts, and connections. Unpublished doctoral dissertation, University of Washington, Seattle.

Sturtevant, E. (2002, September). The literacy coach: A key to improving teaching and learning in secondary schools. Washington, DC: Alliance for Excellent Education.

The Reading Apprenticeship framework. (n.d.). Retrieved April 2, 2008, from http://www.wested.org/cs/sli/print/docs/sli/ra_framework.htm

Tierney, W. G. (1997). Lost in translation: Time and voice in qualitative research. In W. G. Tierney \& Y. S. Lincoln (Eds.), Representation and the text: Re-framing the narrative voice (pp. 23-36). Albany, NY: State University of New York Press.

Toll, C. A. (2004, October). Separating coaching from supervising. English Leadership Quarterly, 5-7.

U.S. Department of Education. (2002). Reading first. Retrieved December 3, 2007, from http://www.ed.gov/programs/readingfirst/legislation.html 
Walpole, S., \& McKenna, M. C. (2006). Literacy coaches in action: Strategies for crafting building-level support systems. Handouts from 2006 IRA Reading Research Conference. Retrieved December 18, 2006, from http://www.reading.org/association/meetings/annual_handouts.html

Wong, K., \& Nicotera, A. (2003). Enhancing teacher quality: Peer coaching as a professional development strategy: A preliminary synthesis of the literature. Washington, DC: Institute of Education Sciences. (ERIC Document Reproduction Service No. ED483035) 



\section{Sharon S. Miller}

\section{Present Position}

January 2006 to present: Southern Tioga School District, Blossburg, PA Supervisor of Curriculum and Instruction

- Supervise K-12 curriculum for 2400 students

- Monitor student academic proficiency progress toward NCLB and PA AYP goals

- Coordinate $\mathrm{K}-11$ reading and math tutoring programs

- Design and implement professional development for staff of $200+$

- Oversee federal and state grant-funded programs

- Responsible for strategic planning process for district

- Coordinate special district programs, as needed

\section{Education}

2004 Bucknell University Lewisburg, PA

Superintendent's Letter of Eligibility

Supervisor of Curriculum and Instruction Certificate

2000 Bucknell University Lewisburg, PA

School Administration \& Supervision, Elementary and Secondary Principal

Certificates

1993 Bucknell University Lewisburg, PA

Secondary Counseling Certificate

1987 Mansfield University Mansfield, PA

Master of Science in Home Economics Education

1981 Mansfield University Mansfield, PA

Bachelor of Science in Home Economics Education

Additional information on leadership experiences and references available upon request.

292 Beech Ridge Road

Trout Run, PA 17771

Phone: Home: 570-998-8118

Work: 570-638-2183, ext. 3004

smiller@southerntioga.org 